\title{
DEFAULT RISK DAN PENJAMINAN KREDIT UKM
}

\author{
Untoro \\ Perry Warjiyo ${ }^{1}$
}

\begin{abstract}
This paper asserts that the credit guarantee for the Usaha Kecil Menengah (UKM, Small-Medium Scale Enterprise) is a necessity to encourage the bank to allocate the credit. This allocation requires the identification of the default risk accompanying the credit allocation, after which, we can define the guarantee capacity of the Lembaga Penjaminan Kredit (LPK) and the risk sharing among the parties.

Using the Merton method, the result shows the default risk of UKM is $0.7 \%$. Next, we apply this value in the gearing ratio method to calculate the credit guarantee capacity, 142 times of the equity owned by the LPK. On practice, this large capacity should be rationalized to maintain the sustainability of the LPK it self.

We analyze five different credit-guarantee schemes based on the involvement of different institutions. The best scheme for a certain region should consider the fund availability and the quality of human resources on the corresponding region.
\end{abstract}

JEL: D81, E51, H81

Keyword: Credit guarantee, default risk, Small-Medium Scale Enterprise, UKM, Merton Method, gearing ratio method

1 Untoro adalah Peneliti Senior di Pusat Pendidikan dan Studi Kebanksentralan, Bank Indonesia (untoro@bi.go.id), Dr. Perry Warjiyo adalah Direktur Direktorat Riset Ekonomi dan Kebijakan Moneter Bank Indonesia (perry_w@bi.go.id) 


\section{PENDAHULUAN}

\section{I.1. Latar Belakang}

Bagi usaha mikro kecil, kredit dirasa cukup penting mengingat kebutuhan untuk pembiayaan modal kerja dan investasi diperlukan guna menjalankan usaha dan meningkatkan akumulasi pemupukan modal mereka. Permasalahan timbul ketika pengusaha mikro kecil tersebut diperhadapkan kepada kelengkapan persyaratan bank guna memperoleh pinjaman. Meskipun usaha mereka feasible namun sebagian besar pengusaha mengalami kesulitan dalam penyediaan asset dalam jumlah yang cukup untuk memenuhi persyaratan jaminan kredit bank.

Usaha yang tidak bankable dipandang oleh bank mengandung "default risk" atau kredit macet. Pada prakteknya untuk menekan resiko kredit macet tersebut bank mewajibkan jaminan tambahan untuk kredit yang diberikan, mengasuransikan baik kredit yang diberikan maupun jaminan kredit yang dimiliki nasabah atau bahkan menolak pemberian kredit meskipun usaha calon debitur memiliki prospek yang sangat memadai. Upaya menekan resiko kredit macet menjadi penghambat bagi upaya perluasan akses kredit bagi usaha - usaha yang feasible.

Adanya resiko kredit macet yang dikawatirkan oleh perbankan berdampak pada rendahnya kucuran kredit UKM. Keadaan ini mendorong beberapa PEMDA untuk menyisihkan dana APBDnya guna membantu pendanaan usaha mikro - kecil. Dana yang disisihkan tersebut disalurkan kepada pengusaha mikro - kecil dalam bentuk pinjaman yang penyalurannya melalui bank. Resiko kemacetan atas penyaluran kredit tersebut sepenuhnya ditanggung oleh PEMDA. Debitur dapat memanfaatkan dana tersebut setelah melalui dua tahap penilaian yaitu melalui tim teknis yang diangkat dengan SK kepala daerah, dan petugas bank (account officer). Pola dengan dana PEMDA dilakukan pula oleh beberapa BUMN atau perusahaan swasta lainnya. Pola tersebut pada dasarnya tidak secara efektif mendorong intermediasi bank.

Dalam upaya mengembangkan UKM dan Koperasi, maka dengan mengacu pada :

a. Surat Keputusan Menteri Keuangan RI Nomer : 486/KMK.017/96, tanggal 30 Juli 1996, tentang Perusahaan Penjaminan; dan

b. Surat Keputusan Bersama Menteri Negara Urusan Koperasi UKM dengan Menteri Dalam Negeri nomer 04/KEP/M/N/2001 dan 518-162 tahun 2001 tanggal 29 Mei 2001 tentang Pembentukan Lembaga Penjaminan bagi Koperasi, Lembaga Keuangan Mikro Non Bank dan UKM di Daerah,

Beberapa daerah mencoba membentuk lembaga penjaminan kredit daerah (LPKD), yang berperan dalam penyediaan jaminan / agunan bagi UKM dan Koperasi yang mengajukan kredit ke perbankan dan lembaga keuangan lainnya. Modal awal yang harus disetor dalam pembentukan LPKD tersebut adalah sebesar Rp 10 milyar. 
Upaya pendirian LPKD tersebut belum dapat dilanjutkan karena terbentur pada dihentikannya pemberian ijin usaha perusahaan penjaminan oleh Menteri Keuangan melalui Surat Keputusan Menteri Keuangan Republik Indonesia, tanggal 23 Oktober 2003, Nomer 479/KMK.06/2003 tentang Penghentian Pemberian ljin Usaha Perusahaan Penjaminan. Alasan dari penghentian pemberian ijin tersebut adalah karena Departemen Keuangan akan mengeluarkan ketentuan baru yang dapat meningkatkan fungsi dan peranan lembaga penjaminan, serta dapat menjaga kelangsungan usaha lembaga penjaminan dimaksud.

Upaya untuk meningkatkan akses kredit UKM ke perbankan mendapat perhatian Bank Indonesia sebagaimana yang tercantum dalam salah satu dari 19 rekomendasi kebijakan perbankan yang harus ditempuh dalam kerangka cetak biru mengenai tatanan industri perbankan ke depan yang dikenal sebagai Arsitektur Perbankan Indonesia (API). Salah satu upaya yang akan dilakukan oleh Bank Indonesia untuk meningkatkan akses kredit perbankan ke sektor riil adalah dengan memfasilitasi pembentukan skim penjaminan kredit.

\section{I.2. Tujuan dan Manfaat Penelitian}

Penelitan ini bertujuan untuk memperoleh hasil perhitungan resiko kredit UKM (default risk) bank yang dapat dialihkan kepada suatu lembaga penjaminan kredit (LPK); mengkaji kapasitas penjaminan dari LPK melalui penghitungan ratio kebutuhan modal LPK untuk dapat menutup resiko penjaminan kredit UKM; dan mengkaji usulan skema penjaminan (risk sharing) untuk kredit UKM diantaranya dengan memanfaat sumber dana dari dana bergulir PEMDA dan atau penyisihan laba BUMN/D.

Dengan diperoleh hasil perhitungan default risk kredit UKM , kapasitas penjaminan kredit UKM oleh LPK dan skema penjaminan kredit, maka diharapkan akan memberikan acuan bagi para pihak yang terlibat dalam pengembangan UKM. Lebih khusus lagi kepada upaya mendorong bank untuk meningkatkan kredit ke sektor usaha mikro kecil.

\section{I.3. Data dan Metodologi Penelitian}

Penelitian dilakukan terhadap kredit usaha mikro - kecil yang diberikan oleh bank-bank umum yang meliputi 6 bank umum dan 6 bank pembangunan daerah. Pemilihan bank umum yang akan dipakai sebagai sample dilakukan dengan mendasarkan pada kepemilikan bank, yaitu bank milik pemerintah (sebanyak 3 sampel) dan bank swasta (sebanyak 3 sampel) dengan memperhatikan total aset dan perhatian yang diberikan kepada UKM. Untuk pemilihan bank BPD yang akan dipakai sebagai sample maka pemilihan diutamakan kepada BPD yang beroperasi 
didaerah yang memiliki UKM cukup besar dan mempertimbangkan pula keterwakilannya pada wilayah teritorial. Sehingga untuk BPD ditetapkan sampel 3 BPD di Pulau Jawa, 2 BPD di Sumatera dan 1 BPD di wilayah timur Indonesia. Di samping penelitian terhadap perbankan, penelitian dilakukan pula kepada PEMDA dan dinas terkait pada propinsi-propinsi tersebut diatas.

Jenis data yang dikumpulkan adalah data primer dan data sekunder. Data sekunder merupakan data kuantitatif yang diperoleh dari laporan bulanan bank dari bank yang dijadikan sample. Sedangkan data primer diperoleh dari wawancara langsung dengan bank, PEMDA dan instansi terkait.

Analisa data dilakukan secara kuantitatif dan kualitatif. Analisa kuantitatif dilakukan dengan mendasarkan pada data laporan bulanan bank dilakukan guna memperoleh default risk dari masing-masing bank untuk selanjutnya dengan dengan pendekatan rata-rata sederhana, dapat diperoleh gambaran default risk perbankan. Penghitungan default risk dilakukan dengan pendekatan Merton. Untuk memudahkan analisa maka kredit perbankan yang dianalisa dibagi atas dasar total kredit bank, dengan mengacu pada kriteria kredit mikro dan kredit kecil, dengan melakukan modifikasi pada kredit kecil. Sehingga analisa dikelompokkan pada:

a. Kelompok kredit bank sampai dengan Rp 50 juta (Kredit Mikro)

b. Kelompok kredit bank antara Rp 50 juta sampai dengan Rp 100 juta,

c. Kelompok kredit bank antara Rp 100 juta sampai dengan Rp 500 juta.

Di samping itu dalam analisa tersebut akan dipisahkan pula analisa antara bank pembangunan daerah (BPD) dengan bank umum lainnya.

Analisa kualitatif dilakukan dengan pendekatan diskriptif dari hasil wawancara di lapangan. Gabungan antara hasil analisa kuantitatif dengan kualitatif dipergunakan untuk mendukung kajian penetapan skema penjaminan kredit yang ideal dipergunakan oleh perbankan di Indonesia.

\section{KAJIAN TEORITIS DAN STUDI KEPUSTAKAAN}

\section{II.1. Landasan Teoritis}

Penjaminan kredit pada dasarnya merupakan upaya untuk menjamin aset dari debitur. Hal ini merupakan upaya untuk melindungi kreditur dari kerugian yang disebabkan terjadinya gagal bayar dari debitur. Perusahaan penjamin kredit sendiri saat ini masih sangat terbatas, di Indonensia hanya kita kenal PT Perum Sarana Pembangunan Usaha, PT Asuransi Kredit Indonensia dan PT Asuransi Ekspor Indonesia (PT ASEI). Beberapa perusahaan asuransi yang 
beroperasi saat ini lebih banyak menjamin bukan pada kredit perbankan namun lebih kepada barang jaminan (aset) atas kredit yang diberikan bank, disamping jaminan asuransi jiwa debitur.

Penjaminan kredit lebih menunjukkan sebagai upaya pembagian resiko. Bank dengan kemampuan analisa kredit yang baik akan memiliki resiko kredit macet yang lebih rendah sehingga mereka akan menetapkan premium risk yang akan rendah pula, dengan demikian akan menekan fee penjaminan kredit yang dibebankan kepada debitur.

\section{II.1.1. Default risk valuation model}

Terdapat beberapa pendekatan dalam mengukur resiko kredit. Dari pendekatan tradisional hingga pendekatan model baru yang dikembangkan disesuaikan dengan perkembangan industri perbankan dan produk-produk perbankan yang ada. Pada umumnya keputusan pemberian kredit diserahkan kepada credit officcer pada masing-masing cabang bank. Sehingga kemampuan officer, judgement dan faktor-faktor penting lainnya sangat diperlukan dalam keputusan kredit. Namun demikian beberapa faktor analisa kredit yang mudah dipahami adalah pendekatan analisa 5 C's, yang meliputi Character, Capital, Capacity, Collateral dan Cycle or Economic conditions.

Selain pendekatan 5 C's tersebut, pemberian kredit didasarkan pula pada analisa tingkat suku bunga yang dapat dibebankan kepada kredit yang akan diberikan. Menurut Stiglitz and Weiss (1981), terdapat hubungan non linier yang tinggi antara tingkat suku bunga dengan expected return dari pada kredit ${ }^{2}$.

Pada saat suku bunga rendah maka expected return atas kredit akan meningkat apabila terjadi peningkatan suku bunga, sedang pada saat suku bunga tinggi maka peningkatan suku bunga akan menurunkan expected return dari loan. Hubungan negatif antara tingginya suku bunga pinjaman dengan expected return menimbulkan dua akibat, yaitu pembatalan kredit atau pengalihan resiko (risk shifting). Ketika suku bunga pinjaman meningkat debitur akan cenderung untuk membiayai dengan dana sendiri proyek mereka, sedangkan debitur yang memiliki keterbatasan dana dan telah terikat pada proyek mereka, maka mereka akan menekan resiko mereka dengan memindahkan resiko tersebut kepada perusahaan penjamin. Apabila keadaan memburuk dan mereka menghadapi "default", mereka akan memiliki limit resiko kerugian yang terbatas.

Resiko kredit macet dapat dipilah dalam empat komponen yang meliputi nominal dari resiko kredit, jangka waktu dari resiko kredit, kemungkinan (probabilitas) kemacetan kredit

2 Saunders Anthony, "Credit risk Measurement, New approaches to Value at Risk and other Paradigms", 1999, p 8. 
dan dampak dari kredit macet tersebut ${ }^{3}$. Keempat aspek tersebut saling terkait dan diperlukan adanya estimasi.

Beberapa metode telah dikembangkan dalam menentukan perkiraan besarnya resiko default kredit, diantaranya adalah Merton's Valuation Model (1974). Dasar model yang dikembangkan oleh Merton adalah mengacu pada struktur keuangan dari suatu perusahaan, dimana suatu default ditentukan oleh nilai pasar dari aset perusahaan yang ada kaitannya dengan hutang perusahaan. Ketika nilai pasar dari aset perusahaan tersebut jatuh (turun) hingga dibawah batas suatu default point, maka perusahaan akan mengalami default credit.

Model Merton dan model lain yang dikembangkan dengan mengacu pada dasar pemikiran Merton mengacu pada struktur aset dari suatu perusahaan adalah terdiri dari hutang dan equity. Dimana dinotasikan total dari hutang (debt) dinyatakan sebagai $B$, dengan jangka waktu kredit dinyatakan sebagai $(T-t)$. Nilai dari perusahaan adalah $A t$.

Dalam Merton model mengasumsikan bahwa perusahaan akan berjanji membayar hutang mereka $(B)$ kepada kreditur pada saat jatuh tempo $(T)$. Bila nilai aset dari perusahaan yang merupakan penjumlahan antara $B$ dan equity kurang dari $B$, maka kreditur akan mengambil alih seluruh perusahaan. Demikian pula sebaliknya pemilik perusahaan akan memiliki kelebihan aset bila saat jatuh tempo kredit maka nilai aset perusahaan di atas nilai hutang pada saat jatuh tempo, maka pemilik perusahaan memiliki nilai lebih.

Dengan demikian kerugian dari resiko default kredit dinyatakan fungsi

$$
\text { Nilai resiko kredit }=f\left(A, \bar{B}, \bar{r}, \sigma_{A}, \bar{\tau}\right)
$$

Dimana: $A=$ nilai pasar dari asset perusahaan

$\bar{B}=$ Total pinjaman

$\bar{r}=$ short term interest rate

$\sigma_{A}=$ Volatilitas nilai pasar dari Asset

$\bar{\tau}=$ Time horizon dari pinjaman

Garis atas pada $\bar{B}, \bar{r}$ dan $\bar{\tau}$ menandakan bahwa data dapat diperoleh secara langsung, sedangkan data tentang $A$ dan $\boldsymbol{\sigma}_{A}$ sulit untuk diperoleh. Untuk mengatasi itu, didalam KMV Credit Monitoring Model yang merupakan pengembangan dari Merton model yang dilakukan oleh KMV Corporation of Sanfransisco melakukan inovasi / penyesuaian dengan cara ${ }^{4}$ :

3 Eales Rob, 1997, Credit Risk Measurement in Corporate Banking - Theory and Practice, Reserve bank of Australia Bank Supervition Department. P 52.

4 Saunders Anthony, 1999, Credit Risk Measurement - New Aproaches to Value at Risk and other Paradigms, John Wiley \& Sons, Inc, p 25 
a) Melakukan pendekatan hubungan struktural antara nilai pasar equity dengan nilai pasar aset perusahaan

b) Melakukan pendekatan hubungan struktural antara volatilitas nilai aset dengan volatilitas nilai equity.

Dengan demikian nilai pasar dari equity adalah :

$$
\bar{E}=h\left(A, \sigma_{A}, \bar{r}, \bar{B}, \bar{\tau}\right)
$$

Dimana volatilitas equity sama dengan pertumbuhan $(g)$ dari volatilitas harga aset

$$
\overline{\sigma_{E}}=g\left(\sigma_{A}\right)
$$

Dengan demikian nilai $\mathrm{A}$ dan $\boldsymbol{\sigma}_{A}$ dapat dihitung.

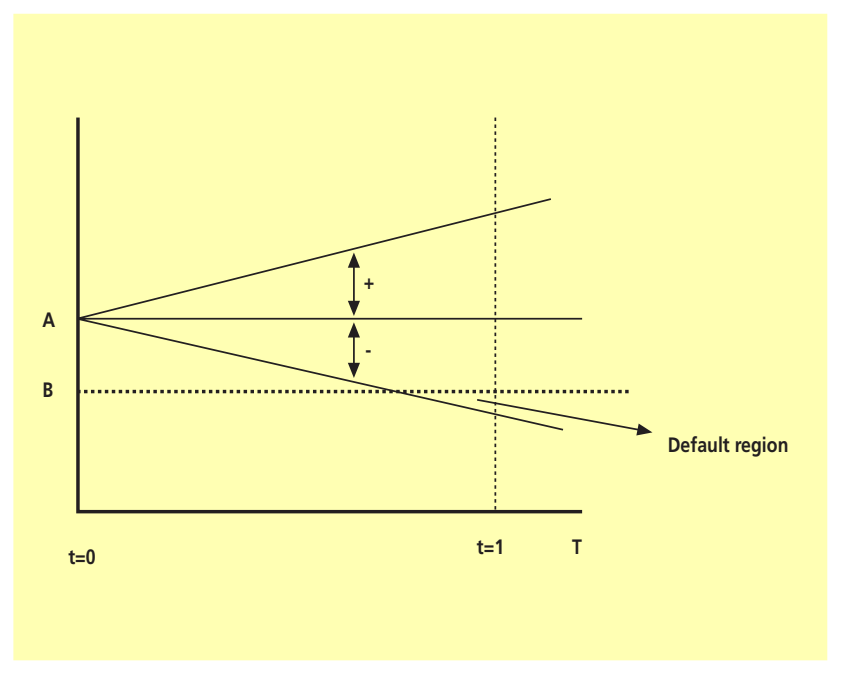

Dari pemikiran tersebut diatas, maka model Merton dapat diterapkan dengan beberapa penyesuaian. Adapun nilai pasar dari piutang yang beresiko dihitung dengan mempergunakan persamaan :

$$
F_{(\tau)}=\mathrm{B} e^{-i \tau}\left[(1 / d) N\left(h_{1}\right)+N\left(h_{2}\right)_{-}^{-}\right.
$$

dimana :

$F_{(\tau)}$ : market value of risky debt

$\tau$ : sisa masa jangka waktu kredit, dalam hal ini $\tau=T-t$; $T$ : jatuh tempo dan $t$ : waktu saat ini atau $t=0$. 


$$
\begin{aligned}
& d \text { : leverage ratio yaitu sebesar } \frac{B e^{-i \tau}}{A} \text {, pada } i \text { risk free risk of interest } \\
& N(h) \text { : probabilitas terjadinya deviasi (volatilitas) } \\
& h_{1}=-\left[1 / 2 \sigma^{2} \tau-\operatorname{Ln}(d)\right] \sigma \sqrt{\tau} \\
& h_{2}=-\left[1 / 2 \sigma^{2} \tau+\operatorname{Ln}(d)\right] \sigma \sqrt{\tau}
\end{aligned}
$$

selanjutnya dengan menggunakan yield spread dapat dihitung default risk premium dengan menggunakan persamaan :

dimana :

$$
k(\tau)-i=(-1 / \tau) \operatorname{Ln}\left\lfloor N\left(h_{2}\right)+(1 / d) N\left(h_{1}\right)\right\rfloor
$$

$$
\begin{aligned}
k(\tau) & =\text { risk spread atau premium untuk risky debt } \\
L n & =\text { natural logaritma, } \\
i & =\text { risk free risk untuk jangka waktu maturity. }
\end{aligned}
$$

Model yang dikemukakan oleh Merton tersebut tidak dapat secara langsung digunakan dalam kajian terhadap usaha kecil di Indonesia karena :

a. Tidak tersedia data mengenai nilai pasar atas asset maupun nilai pasar atas equity, karena tidak semua perusahaan telah "go public", khususnya terhadap usaha mikro kecil.

b. Perlu dilakukan modifikasi atas volatilitas harga asset atau volatilitas equity dengan mengacu pada besaran atau variabel tertentu yang dapat mewakili volatilitas harga asset maupun equity.

c. Model Merton dipergunakan untuk menganalisa debitur individual, sedangkan dalam penelitian ini digunakan untuk kelompok debitur sehingga perlu pendekatan agar diperoleh kelompok debitur yang mendapat perlakuan relatif sama antara satu dengan lainnya oleh bank pemberi kredit.

Untuk itu beberapa penyesuaian dilakukan untuk penerapan pada perhitungan default risk bagi usaha mikro kecil sebagai berikut:

a. Mengganti nilai aset $(A)$ dengan penjumlahan nilai kredit dan nilai agunan, karena tanggung jawab debitur terhadap hutang bank sepenuhnya tergantung pada nilai agunan yang dijaminkan. Nilai kredit dan agunan ini merupakan nilai proyek dan nilai barang agunan, karena khususnya pada usaha mikro-kecil, jaminan utama dari kredit yang diberikan adalah proyek itu sendiri, sedang agunan di luar proyek merupakan agunan tambahan.

b. Untuk mengukur volatilitas ( $\sigma$ ) nilai kredit dan agunan, yang merupakan nilai aset, karena ketidak tersedianya data maka dipergunakan pendekatan perubahan indeks harga saham gabungan. Perubahan harga saham dipengaruhi oleh selain kondisi internal perusahaan, 
dipengaruhi pula oleh faktor fundamental ekonomi dan perkembangan politik. Perkembangan faktor fundamental tersebut selain dapat mempengaruhi perubahan harga saham secara individual, dapat pula mempengaruhi harga saham dari suatu kelompok industri atau pergerakan pasar saham secara keseluruhan ${ }^{5}$. Para pelaku pasar saham melakukan forcast terhadap tren harga saham, dimana dalam melakukan prediksi harga saham tersebut mendasarkan pada perkiraan perubahan fundamental yang terjadi di pasar. Apabila mayoritas dari pelaku saham meyakini bahwa kondisi fundamental menunjukkan tren bullish maka mereka akan melakukan aksi pembelian saham, akibatnya indeks saham akan naik demikian pula sebaliknya apabila mereka memperkirakan terjadi hal yang negatif terhadap perkembangan fundamentalnya maka pelaku pasar akan melakukan tindakan penjualan saham sehingga indeks akan mengalami penurunan. Dari kajian historis menunjukkan bahwa pergerakan harga saham (indeks harga saham) terkait erat dengan perkembangan ekonomi dan politik, walaupun kadang-kadang terjadi lead maupun lag terhadap perkembangan ekonomi dan atau politik suatu negara. Oleh karena pergerakan harga saham terkait dengan perkembangan ekonomi maka indeks harga saham dipergunakan dalam kajian mengenai default risk untuk mewakili volatilitas harga aset.

c. Data yang dipergunakan untuk risk free rate (I) adalah rate untuk asset yang mempunyai resiko paling minim yaitu suku bunga SBI yang berlaku pada saat periode penghitungan.

d. Agar model Merton dapat dipergunakan untuk analisa kelompok debitur, maka dalam kajian ini dilakukan pengelompokkan debitur atas dasar nominal kredit, bank pemberi kredit dan perwilayahan usaha yang diwakili dengan cara analisa terhadap kredit yang disalurkan oleh BPD

\section{II.1.2. Kecukupan Modal Lembaga Penjaminan Kredit}

Dalam kaitan dengan kecukupan modal lembaga penjaminan kredit, Departemen Keuangan hanya mengeluarkan ketentuan mengenai modal minimum bagi pembentukan lembaga penjaminan kredit. Dalam SK Menteri Keuangan No 486/KMK.017/1996 tanggal 30 Juli 1996, tentang Perusahaan Penjaminan ditetapkan bahwa modal minimum pendirian lembaga penjaminan kredit adalah sebesar Rp 10 milyar. Sedangkan untuk ketentuan yang mengatur kewajiban lembaga keuangan menjaga posisi keuangan setiap saat belum dikeluarkan. Namun, terhadap perusahaan asuransi, pemerintah melalui SK Menteri Keuangan Republik Indonesia No 424/KMK.06/2003 tanggal 23 September 2003, tentang Kesehatan Keuangan Perusahaan Asuransi dan Perusahaan Reasuransi, mengatur tingkat minimum solvabilitas bagi

5 Teweles J. Richard, Bradley S. Edward, Teweles M. Ted, 1992, The Stock Market, John Wiley \& Sons, Inc, Canada, 6th edition, p 424 
perusahaan asuransi dan reasuransi sebesar minimal 120\% dari resiko kerugian yang mungkin timbul sebagai akibat dari deviasi dalam pengelompokan kekayaan dan kewajiban.

Untuk menghitung kebutuhan modal minimum atau mengukur kapasitas suatu lembaga penjaminan dalam menjamin kredit usaha mikro kecil, maka akan mendasarkan pada analisa resiko finansial (financial risk). Karena belum ada peraturan yang dikeluarkan oleh pemerintah maka analisa akan menggunakan alat analisa gearing ratio. Banyak tersedia alat analisa untuk mengukur resiko finansial, namun gearing ratio merupakan salah satu indikator risiko finansial yang paling penting ${ }^{6}$. Gearing ratio (GR) mencerminkan ratio antara total liabilities dengan modal, atau sering disebut sebagai debt to equity ratio, dengan rumus persamaan sebagai berikut

\section{Gearing Ratio $=\frac{\text { Current }+ \text { FixedLiabilities }}{\text { Equity }}$}

makin tinggi ratio maka menunjukkan posisi keuangan perusahaan makin tidak menguntungkan (buruk), atau dengan kata lain makin rendah rasio hutang terhadap modal perusahaan maka posisi solvabilitas perusahaan lebih baik ${ }^{7}$.

Dikaitkan dengan lembaga penjaminan, maka total liabilities tersebut merupakan perkiraan default risk dari kredit yang dijamin oleh lembaga tersebut. Perkiraan default risk dapat diperoleh dari hasil perhitungan default risk dengan pendekatan Merton, dan sebagai pembanding data default risk diperoleh dari kolektibilitas kredit yang mempunyai kriteria macet, sesuai ketentuan Bank Indonesia. Setelah diperoleh hasil perhitungan tingkat gearing ratio, maka dengan mengalikannya dengan total equity dari LPK maka akan diperoleh kapasitas penjaminan dari LPK dimaksud.

\section{II.2. Penjaminan Kredit Usaha Mikro - Kecil}

Penjaminan kredit adalah kegiatan pemberian penjaminan kepada koperasi, usaha kecil dan menengah yang tidak memiliki agunan atau agunannya tidak mencukupi agar dapat memperoleh kredit dari perbankan atau badan usaha pemberi kredit lainnya ${ }^{8}$. Penjaminan kredit berbeda dengan asuransi kredit, karena dalam asuransi kredit resiko yang dijamin adalah resiko bank, sedang dalam penjaminan kredit maka yang dijamin adalah debitur sedang perusahaan penjaminan adalah sebagai penjamin. Disamping itu di dalam penjaminan kredit dikenal adanaya piutang subrogasi, yaitu kewajiban debitur untuk melunasi hutangnnya kepada

6 Coleshaw John, 1989,Credit Analysis - How To Measure and Manage Credit Risk, Woodhead-Faulkner, Cambank umum 3dge England, p 76.

7 Gibson H. Charles, 1998, Financial Statement Analysis, South-Western College Publishing, Cincinnati - Ohio, p 329

8 www.perum-sarana.com 
perusahaan penjamin atas kerugian yang telah dibayarkan perusahaan penjamin kepada kreditur akibat kemacetan kredit debitur.

Pendirian perusahaan penjaminan kredit dalam praktek di beberapa negara, pada umumnya diprakarsai oleh pemerintah. Alasan dari penerapan penjaminan kredit pada dasarnya antara negara satu dengan yang lain adalah sama, yaitu memberikan motivasi kepada bank agar mengucurkan kredit kepada kelompok usaha yang tidak memiliki akses kredit dalam persyaratan standar kredit.

Secara teoritis terdapat beberapa jenis skema penjaminan kredit, sebagaimana yang disampaikan oleh Alvaro Ruiz Navajas ${ }^{9}$, yaitu

a. Direct Model dan Indirect Model.

Skema penjaminan ini lebih memperhatikan sistem hubungan antara debitur dengan penjamin. Dalam model langsung (direct model) maka penjaminan diberikan oleh penjamin kepada debitur atas dasar pengajuan penjaminan dari bank. Penjamin akan menutup kerugian dalam jumlah tertentu apabila terjadi default sesuai dengan perjanjian. Sedang dalam model tidak langsung (indirect model), maka penjamin menempatkan dana penjaminan di bank, dan program penjaminan dilakukan tanpa keterlibatan secara langsung dari penjamin. Penjamin kredit hanya menerima progress report saja.

b. Individual model dan portfolio model

Model ini dikaitkan dengan cara penjaminan kredit. Dalam individual model, debitur secara individu akan dijamin kreditnya oleh lembaga penjaminan setelah memperoleh persetujuan kredit dari bank. Debitur harus membayar fee penjaminan yang besarnya disesuaikan dengan total kredit atau jumlah kredit yang dijaminkan. Sedangkan di dalam portfolio model, jaminan tidak diberikan secara individual melainkan penjamin akan secara otomatis memberikan jaminan kepada kredit yang di cairkan oleh bank sepanjang memenuhi kriteria yang telah disepakati oleh kedua belah pihak. Keuntungan dari porfolio model adalah maksimum kerugian akibat default dapat diperkirakan sebelumnya.

c. Funded Model dan Unfunded Model

Model ini dikaitkan dengan sumber dana penjaminan. Funded model adalah model penjaminan dimana dana penjaminan tidak berasal dari pemerintah namun dapat berasal dari dari bank sentral, atau perbankan atau sumber dana bersama antara perbankan dan non perbankan. Dalam hal unfunded model, pemerintah menempatkan sejumlah dana di bank guna menjamin kredit yang diberikan oleh bank. Apabila terjadi default, maka bank ikut menanggung resiko yang pada umumnya maksimum sebesar $25 \%$.

9 Navajas Ruiz Alvaro, 2001, Credit Guarantee Schemes : Conceptual Frame, Financial System Development Project, GTZ/FONDESIF, p $4-8$ 
d. Open model dan target (close) model

Dalam model ini dikaitkan dengan kelompok pengusaha yang akan dijamin. Dikatakan sebagai open model bila penjaminan diberikan kepada kelompok debitur tertentu tanpa dikenakan persyaratan tambahan. Sedang dalam close model, maka terhadap kelompok debitur tersebut dikenakan persyaratan tertentu sebagai persayaratan tambahan.

e. Ex-ante Model dan Ex-post Model Model ini mendasarkan pada waktu penerbitan penjaminan. Dalam model Ex-ante, maka debitur akan mengajukan permohonan penjaminan terlebih dahulu kepada lembaga penjaminan, apabila disetujui maka akan diterbitkan surat penjaminan untuk selanjutnya oleh calon debitur dipakai guna mengajukan permohonan kredit bank. Bank dapat menolak permohonan kredit calon debitur tersebut bila menurut penialain bank, usaha debitur tidak layak dibiayai. Sedang dalam model Ex-post, maka pengajuan penjaminan dilakukan setelah ada persetujuan kredit. Biasanya pengajuan penjaminan dilakukan oleh bank.

f. Intermediary model.

Penjaminan diberikan kepada bank yang memberikan kredit kepada lembaga keuangan mikro, dimana kredit bank tersebut dipergunakan oleh lembaga keuangan mikro untuk membiayai kredit usaha mikro.

\section{II.2.1. Praktek Penjaminan Kredit Usaha Mikro-Kecil di Indonesia}

Praktek penjaminan kredit di Indonesia dilakukan oleh PT Asuransi Kredit Indonesia (PT ASKRINDO) yang didirikan bersama oleh Bank Indonesia dan Pemerintah, Perum Sarana Pembangunan Usaha (PSPU) yang kepemilikannya sepenuhnya oleh pemerintah dan PT Penjaminan Kredit Pengusaha Indonesia (PT PKPI) yang didirikan oleh swasta (KADIN 60\% dan pengusaha secara perorangan 40\%). Ketiga LPK tersebut dalam kegiatannya tidak hanya mengkonsentrasikan diri pada penjaminan kredit namun melakukan kegiatan penjaminan lainnya. Dalam melaksanakan penjaminan terhadap UKM ketiga LPK tersebut menggunakan dua pola yaitu Conditional Automatic Cover (CAC) dan Case by Case (CBC).

Dalam pola CAC, dilaksanakan setelah dilakukan perjanjian kerjasama antara bank dengan LPK. Penjaminan yang bersifat otomatis ini berlaku untuk plafon kredit maksimum Rp 100 juta bagi Perum Sarana dan plafon kredit Rp 500 juta bagi PT Askrindo. Dalam pola ini digunakan dua sistem penjaminan yaitu conventional system dan Stop Loss System. Pada system konvensional, dimana LPK akan menjamin penggantian sebesar $70 \%$ dari kerugian yang terjadi pada portfolio bank (kredit yang diberikan). Sedangkan pada sistem stop loss akan menjamin 70\% dari prosentase tertentu dan portfolio kredit bank. 
Penerapan pola CAC oleh PT PKPI dilakukan dengan bank yang telah melakukan penandatanganan perjanjian kerjasama, saat ini telah dilakukan dengan 7 bank dan 4 lembaga pembiayaan usaha. Penjamin akan memberikan penjaminan setelah menerima pengajuan dari bank/lembaga pembiayaan dengan nilai penggantian antara $50 \%$ hingga $80 \%$ dari outstanding. Apabila penjamin ikut menilai secara langsung pengajuan kredit debitur maka penggantian dapat mencapai 80\%, namun apabila penilaian kredit diserahkan sepenuhnya kepada bank maka penggantian mencapai 50\% .

Pada penjaminan dengan pola case by case (CBC), maka program penjaminan dapat diajukan oleh bank maupun oleh calon debitur secara individual. Besarnya jaminan dalam pola ini bervariasi tergantung kepada resiko usaha calon debitur. PT Askrindo menetapkan besarnya jaminan berkisar antara $60 \%$ - 100\% dari total kerugian, Perum Sarana menetapkan sebesar 50\% - 80\% dari total kerugian sedang PT PKPI menetapkan sebesar 50\%-80\% dari outstanding kredit.

Dalam menetapkan fee penjaminan, PT Askrindo menetapkan sebesar 1,5\% dari plafon kredit. Perum Sarana menetapkan fee penjaminan bervariasi disesuaikan dengan jangka waktu dan agunan tambahan yang ada serta sektor usaha. Untuk kredit umum sektor agribisnis fee penjaminan jangka waktu satu tahun sebesar 1,5\%, sedang untuk kredit non agribisnis dan flexible coverage dengan tanpa memperhatikan jaminan tambahan ditetapkan antara 0,5\% hingga 1,35\% tergantung pada jangka waktunya. Untuk kredit dengan memperhatikan jaminan tamabahan (fixed coverage) maka untuk penjaminan jangka waktu 1 tahun dengan agunan hingga 50\% maka fee penjaminan sebesar 1,35\%, untuk agunan antara 50\%-70\% maka fee penjaminan sebesar 1,30\% dan untuk agunan tambahan diatas $70 \%$ maka fee penjaminan sebesar 1,25\%. Fee penjaminan yang ditetapkan PKPI ditetapkan sebesar 1\%-1,5\% dari outstanding kredit, dengan penetapan besarnya fee penjaminan tersebut dikaitkan dengan agunan tambahannya.

\section{II.2.2. Praktek Penjaminan Kredit Usaha Mikro-Kecil di Beberapa Negara}

A. Skema Penjaminan Kredit oleh The Small Industry Credit Guarantee Corporation (SICGC) Thailand

Small Industry Credit Guarantee Corporation (SICGC) adalah LPK di Thailand yang beroperasi sejak 21 Pebruari 1992, dengan tujuan utama memberikan jaminan kredit kepada kredit yang mengalami kekuarangan collateral. Oleh karena itu SICGC merupakan organisasi non profit dan dimiliki oleh pemerintah $(93,18 \%)$, asosiasi Bank-bank swasta $(2,50 \%)$, bank milik pemerintah $(1,53 \%)$, bank tabungan negara $(1,44 \%)$ Industrial Financial Corporation of 
Thailand (1,08\%), dan Small and Medium Enterprise Development Bank (0,27\%). Lembaga penjamin kredit tersebut memiliki empat skim penjaminan yang meliputi normal scheme, automatic scheme, NPL scheme dan risk participation scheme.

Dalam skema normal, penjaminan diperuntukkan bagi pinjaman yang tidak didukung oleh agunan untuk golongan kredit dengan plafon maksimum tertentu (dalam hal ini senilai 40 juta baht). Dengan maksimum penjaminan hingga mencapai 100\% dari total kredit yang tidak ada agunannya tetapi tidak melebihi $50 \%$ dari total pinjaman serta maksimum nilai penjaminan tidak melebihi jumlah tertentu. Syarat lain yang harus dipenuhi dari debitur adalah adanya personal garansi dan fee penjaminan bersifat tetap yaitu sebesar 1,75\% per tahun dibayar dimuka.

Kriteria dalam automatic scheme hampir sama dengan normal scheme, hanya saja nilai penjaminan lebih rendah (yaitu maksimum 10 juta baht) dengan minimal equity tidak kurang dari $20 \%$ dari nilai proyek investasi.

Non Performing Loan scheme merupakan program kerja sama antara SICGC dengan bank sentral dalam rangka restrukturisasi hutang. Dalam skim ini, bank menanggung resiko kredit hingga $75 \%$ dari porsi kredit yang tidak didukung agunan, dan SICGC baru membayar klaim bila sudah ada putusan pengadilan.

Dalam risk participation scheme, maka resiko kredit akan ditanggung bersama antara bank dengan SICGC, dimana SICGC akan membayar 50\% dari perkiraan kerugian bagi bank meskipun belum ada keputusan dari pengadilan. Fee penjaminan sebesar 1,75\% pertahun dibayar dimuka oleh peminjam dan maksimum penjaminan sebesar $50 \%$ dari total pinjaman.

\section{B. Skema Penjaminan Kredit oleh The Small Business Guarantee and Finance Corporation (SB Corporation) - Philippines}

The Small Business Guarantee and Finance Corporation (SB Corporation) didirikan pada tahun 1991 namun beroperasi sebagai lembaga penjaminan kredit untuk usaha kecil dilaksanakan pada November 2001, dengan kepemilikan terdiri 57\% dikuasai 5 (lima) lembaga keuangan milik pemerintah dan $43 \%$ dimiliki oleh pemerintah pusat.

Penjaminan dilakukan sebagai pengganti agunan atau sebagai tambahan agunan kredit dan program penjaminan diperuntukkan kepada kelompok usaha manufacturing dan jasa, investasi bidang agrobisnis dan industri yang mendukung kegiatan perusahaan besar. Dengan fee penjaminan ditetapkan sebesar $2 \%$ p.a. dari nilai penjaminan dan processing fee sebesar 0.1 dari $1 \%$ dari total kredit. Dalam periode 90 hari sejak penjaminan disetujui maka persetujuan kredit harus dikeluarkan. 
Adapun maksimum penjaminan kredit adalah sebagai berikut :

\begin{tabular}{|c|c|c|}
\hline & Kredit tanpa jaminan barang tetap & Kredit dengan jaminan barang tetap \\
\hline $\begin{array}{l}\text { Start - Up Projects } \\
\text { a. Local Producer } \\
\text { b. Fanchisees } \\
\text { c. New Exporter }\end{array}$ & $\begin{array}{l}60 \% \\
60 \% \\
\text { o } 85 \% \text { (untuk transaksi dengan } \\
\text { Irrevocable L/C) } \\
\text { o } 60 \% \text { (untuk transaksi dengan kombinasi } \\
\text { antara Irrevocable L/C dan confirmend } \\
\text { P/O) } \\
70 \% \text { atau } \\
\text { 80\% untuk kredit ekspor yg didukung } \\
\text { irrevocable L/C }\end{array}$ & $\begin{array}{l}\qquad 8 \% \\
80 \% \\
\text { o } 85 \% \text { (untuk transaksi dengan } \\
\text { Irrevocable L/C) } \\
\text { o } 80 \% \text { (untuk transaksi dengan kombinasi } \\
\text { antara Irrevocable L/C dan confirmend } \\
\text { P/O) } \\
85 \%\end{array}$ \\
\hline
\end{tabular}

\section{Skema Penjaminan Kredit oleh The Credit Guarantee Corporation Bhd - Malaysia}

The Credit Guarantee Corporation Bhd (CGC) didirikanpada 5 Juli 1972 dengan kepemilikan terdiri dari Bank Negara Malaysia (79,3\%) dan Commercial Bank \& Financial Companies $(20,7 \%)$. Saat ini CGC memiliki 7 skema penjaminan yang disesuikan dengan fasilitas pembiayaan bank. Skema penjaminan tersebut meliputi New Principal Guarantee Scheme (NPGS), Direct Access Guarantee Scheme (DAGS), Islamic Banking Guarantee Scheme (IBGS), Small Entreprenuer Guarantee Scheme (SEGS), Special Relief Guarantee Facility (SRGF), Flexi Guarantee Scheme (FGS) dan Franchise Financing Scheme (FFS).

Penjaminan diajukan oleh bank kepada CGC setelah bank menerima aplikasi pengajuan kredit dari calon debitur. Peserta dari program penjaminan ini meliputi 23 bank komersial dan 10 lembaga keuangan yang beroperasi di Malaysia. Sedangkan kriteria perusahaan yang dapat menerima program penjaminan adalah perusahaan yang mayoritas dimiliki oleh warga negara Malaysia dengan sales turn over tidak melebihi RM 25 juta atau jumlah pegawai tetap tidak lebih dari 150 orang. Fee penjaminan sebesar 1\% dan 1,25\% tergantung pada agunan kredit, dengan resiko penjaminan mencapai hingga $90 \%$ dari total kredit bagi kredit dengan agunan yang memadai dan penjaminan mencapai hingga $80 \%$ untuk kredit tanpa agunan yang memadai. Agunan atas nama CGC akan disimpan oleh bank.

\section{ANALISIS HASIL PERHITUNGAN DEFAULT RISK}

Perhitungan default risk bank dilakukan dengan menggunakan metode Merton, menghasilkan rata-rata tingkat default risk untuk kredit mikro sebesar 0,77\%, kredit kecil 
dengan plafon sampai dengan Rp 100 juta sebesar 0,67\% dan kredit kecil dengan plafon antara Rp 100 juta hingga Rp 500 juta sebesar 0,65 \%. Sehingga rata-rata default risk untuk semua plafon sebesar $0,70 \%$.

Dari perhitungan dengan menggunakan metode Merton dapat dilihat adanya fluktuasi default risk dari masing-masing bank untuk plafon kredit yang berbeda. Fluktuasi default risk terjadi karena adanya volatilitas harga aset yang diukur dengan menggunakan volatilitas indeks harga saham gabungan. Dalam situasi nilai aset yang berfluktuasi, beberapa bank tidak mengalami peningkatan default risk yang berarti, sedangkan yang lainnya akan menunjukkan peningkatan default risk. Hal ini terjadi karena beberapa bank sangat berhatihati dalam pemberian kredit kepada masyarakat dengan cara mewajibkan kepada debitur untuk menyerahkan agunan dengan nilai yang tinggi, bahkan melebihi nilai kreditnya. Karena dalam default risk dengan metode Merton tersebut, peneliti telah menetapkan nilai aset sebagai penjumlahan antara nominal kredit dan nilai agunan, maka makin tinggi agunan maka faktor penghitung nilai aset makin tinggi. Konsekuensinya pada saat terjadi fluktuasi nilai aset, maka kredit dengan nilai agunan yang besar akan menghasilkan default risk yang rendah demikian sebaliknya terhadap kredit yang tidak didukung dengan agunan maka akan menghadapi default risk yang lebih tinggi.

Dibandingkan dengan tingkat kemacetan kredit sebagaimana yang ditetapkan oleh Bank Indonesia, hasil perhitungan default risk dengan menggunakan metode Merton menunjukkan kecenderungan hasil tingkat default yang lebih rendah. Hanya pada saat terjadi flutuasi nilai aset yang besar maka tingkat default risk lebih tinggi dari tingkat kredit macet bank. Perbedaan ini terjadi sebagai akibat perbedaan paradigma antara cara penghitungan default risk dengan menggunakan metode Merton, dibanding dengan kriteria kredit macet Bank Indonesia. Metode Merton menggunakan pendekatan "forward looking", dimana penghitungan kredit macet dilakukan dengan mendasarkan pada perkembangan suku bunga dan volatilitas harga aset, sedangkan metode Bank Indonesia lebih menekankan pada pendekatan "backward looking", yaitu tanpa mengkaitkan dengan nilai aset dari debitur.

\section{III.1. Analisis Default Risk Kredit Mikro}

\section{III.1.1. Analisis Default Risk Kredit Mikro Bank Umum non BPD}

Untuk kredit mikro Bank Umum 1 dan Bank Umum 4 mempunyai tingkat default risk dibawah 0\% atau minus, dengan rata-rata default risk Bank Umum 1 pada tahun 2002 sebesar -0,76\% dan tahun 2003 mencapai -0,49\% sedangkan untuk Bank Umum 4 mencapai - 17\% tahun 2002 dan $-0,19 \%$ tahun 2003, dan untuk bank lainnya menunjukkan perkembangan 
peningkatan default risk. Secara keseluruhan rata-rata tingkat default risk perbankan non BPD untuk kredit mikro pada tahun 2002 sebesar 0,02\%, pada tahun 2003 sebesar 0,55\%, dan rata-rata selama tahun 2002 hingga 2003 sebesar 0,28\%. Perkembangan default risk bank umum untuk kredit mikro tersebut sejalan dengan fluktuasi dari perkembangan IHSG.

Apabila dikaitkan dengan tingkat kredit macet sesuai kriteria kredit macet yang ditetapkan oleh Bank Indonesia, maka meskipun dalam perhitungan default risk untuk kredit mikro menunjukkan tingkat default risk minus pada beberapa bank, ternyata seluruh perbankan menghadapi kredit macet. Bahkan beberapa bank menghadapi kredit macet yang relatif tinggi walaupun pada tahun 2003 secara rata-rata berhasil diturunkan.

Meskipun faktor penghitung default risk yang dipakai sama untuk semua bank, yaitu dengan mengacu pada volatilitas IHSG sebagai indikator volatilitas dari aset debitur, namun karena perbedaan jumlah agunan tambahan yang dipersyaratkan oleh bank telah menyebabkan perbedaan tingkat default risk bank untuk kredit mikro. Beberapa bank dengan agunan tambahaan yang rendah masih memiliki tingkat default risk yang rendah yaitu kurang dari 1,5\%, seperti yang terlihat pada Bank Umum 3. Untuk Bank Umum 1 dan Bank Umum 4

\begin{tabular}{|c|c|c|c|c|}
\hline & Default & $\begin{array}{l}\text { Krd Macet } \\
\text { kriteria BI }\end{array}$ & Agunan Krd & $\begin{array}{l}\text { Share thd } \\
\text { total krd }\end{array}$ \\
\hline & \multicolumn{4}{|c|}{2002} \\
\hline BANK UMUM 1 & -0.76 & 0.43 & 645.0 & 0.94 \\
\hline BANK UMUM 2 & 0.14 & 0.51 & 23.0 & 3.71 \\
\hline BANK UMUM 3 & 0.41 & 0.70 & 4.33 & 33.2 \\
\hline BANK UMUM 4 & -0.17 & 2.21 & 132.8 & 2.27 \\
\hline BANK UMUM 5 & 0.44 & 2.98 & 3.0 & 2.61 \\
\hline BANK UMUM 6 & 0.05 & 12.2 & 14.6 & 0.83 \\
\hline \multirow[t]{2}{*}{ IHSG_STDEV } & 11.9 & & & \\
\hline & \multicolumn{4}{|c|}{2003} \\
\hline BANK UMUM 1 & -0.49 & 0.57 & 433.5 & 0.53 \\
\hline BANK UMUM 2 & 0.47 & 0.54 & 15.4 & 3.85 \\
\hline BANK UMUM 3 & 1.44 & 1.04 & 5.35 & 30.8 \\
\hline BANK UMUM 4 & -0.19 & 1.74 & 159.0 & 1.35 \\
\hline BANK UMUM 5 & 1.19 & 0.86 & 8.1 & 1.43 \\
\hline BANK UMUM 6 & 0.89 & 9.5 & 26.6 & 0.73 \\
\hline IHSG_STDEV & 14.6 & & & \\
\hline
\end{tabular}


dengan tingkat default yang selalu minus terjadi karena perlakuan yang sangat hati-hati kepada debitur melalui persyaratan pemenuhan agunan tambahan yang jauh melebihi kredit yang diberikan. Rata-rata agunan kredit mikro Bank Umum 1 pada tahun 2002 mencapai $645 \%$ dan tahun 2003 mencapai 433,5 \%, sedang untuk Bank Umum 4 mencapai rata-rata 132,8\% pada tahun 2002 dan 159,0\% pada tahun 2003. sedangkan untuk bank lainnya berkisar antara $3 \%$ hingga $26 \%$.

Dengan memperhatikan tingkat default risk dan nilai agunan, maka dapat ditarik kesimpulan bahwa untuk kredit mikro, resiko kredit macet yang dihadapi oleh bank, sepanjang penilaian kredit sesuai prosedur bank, bukan merupkan akibat rendahnya nilai agunan namun merupakan akibat dari volatilitas harga aset yang tercermin dari volatilitas IHSG.

Dibanding dengan total keseluruhan kredit yang disalurkan oleh bank, jumlah kredit mikro pada Bank Umum sangat rendah yaitu rata-rata kurang dari 4\% pada tahun 2003 di masing-masing bank kecuali pada Bank Umum 3 yang mencapai share sebesar 30,8\% tahun 2003. Hal ini menunjukkan segmen pasar kredit mikro kurang diminati oleh kalangan Bank Umum non BPD.

\section{III.1.2. Analisis Default Risk Kredit Mikro Bank Pembangunan Daerah}

Hasil perhitungan default risk untuk Bank Pembangunan Daerah (BPD) menunjukkan tren meningkat khususnya dalam tahun 2003, yaitu pada dua triwulan terakhir tahun 2003. Peningkatan default risk pada periode tersebut searah dengan meningkatnya resiko harga aset yang tercermin dari meningkatnya volatilitas IHSG sebagai cerminan dari volatilitas harga aset, walaupun pada saat yang sama suku bunga SBI jangka waktu 3 bulan masih menunjukkan penurunan.

Akibat meningkatnya volatilitas aset, maka default risk untuk kredit mikro BPD rata-rata tahun 2003 mengalami peningkatan. Posisi default risk tertinggi dialami oleh BPD 3 sebesar 2,5\% selanjutnya berturut-turut BPD 1 sebesar 2,4\%, BPD 5 sebesar 2,04\%, BPD 4 sebesar $1,98 \%$, BPD 2 sebesar 1,7\%, dan BPD 6 sebesar 1,66\%. Sedangkan secara keseluruhan defaul risk BPD untuk tahun 2003 sebesar 2,05\% dan tahun 2002 sebesar 0,48\%. Peningkatan ini terjadi pada saat rata-rata volatilitas IHSG meningkat dari 11,9\% tahun 2002 menjadi 14,6\% tahun 2003.

Pada periode yang sama, kredit macet untuk kredit mikro BPD menurut kriteria Bank Indonesia mengalami peningkatan dari rata-rata tahun 2002 sebesar 0,86\% menjadi rata-rata sebesar 1,25\% pada tahun 2003. Hal ini menunjukkan bahwa default risk menurut perhitungan 


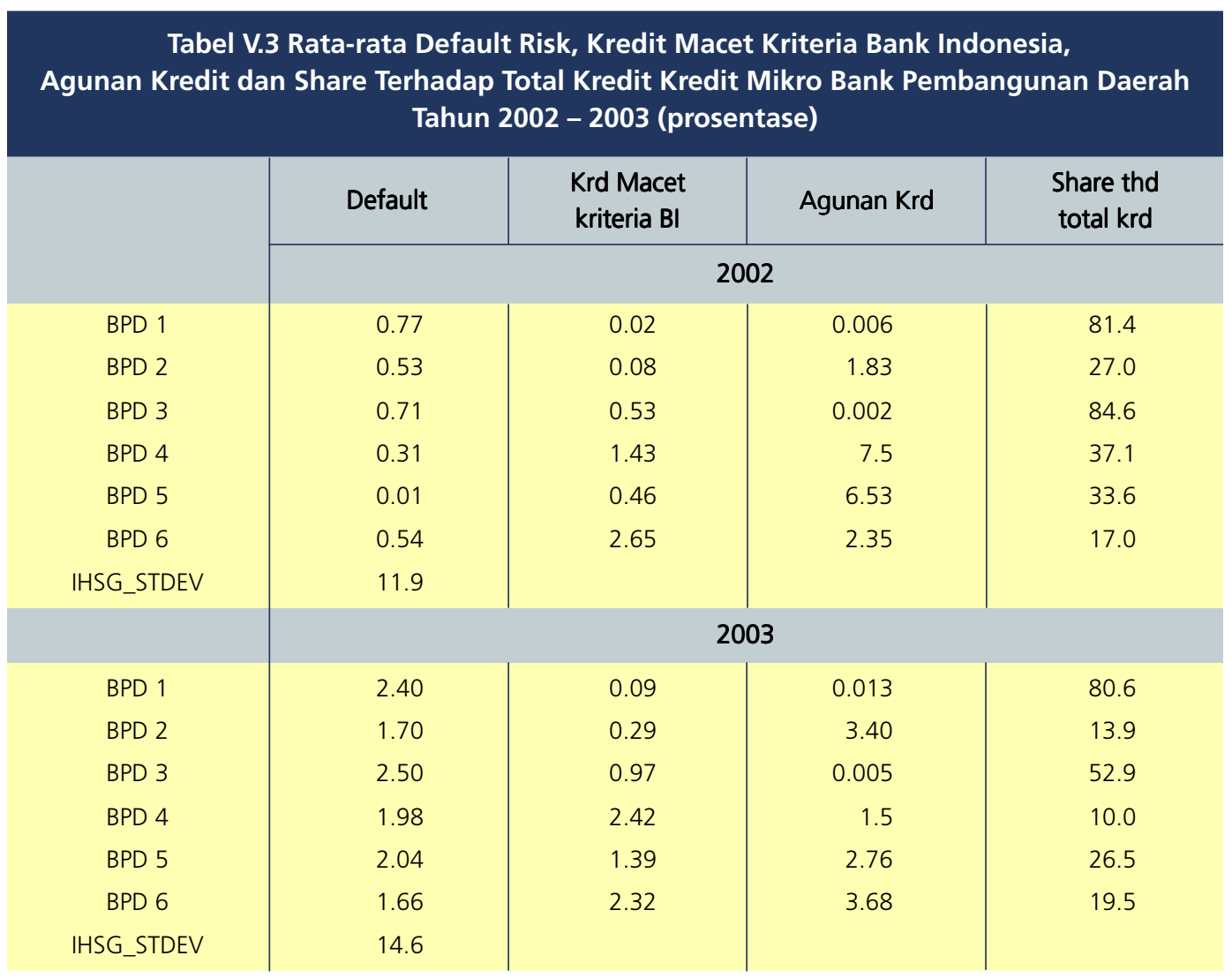

dengan menggunakan metode Merton lebih tinggi dibanding kredit macet kriteria Bank Indonesia.

Agunan kredit mengalami penurunan dari rata-rata bank sebesar 3,04\% pada tahun 2002 menjadi 1,89\% pada tahun 2003, namun penurunan tersebut hanya terjadi pada dua BPD yaitu BPD 4 dari rata-rata agunan 7,5\% tahun 2002 menjadi 1,5\% tahun 2003 dan agunan pada BPD 5 dari 6,53 \% tahun 2002 menjadi 2,76 \% tahun 2003. Sedangkan agunan pada BPD lainnya mengalami peningkatan.

Perhatian BPD terhadap kredit mikro dapat dilihat pada share kredit mikro terhadap total kredit. Kebijaksanaan pemberian kredit dengan konsentrasi kredit kepada usaha mikro diperlihatkan oleh BPD 1 dengan share kredit mikro terhadap total kredit mencapai 80,6\% tahun 2003, selanjutnya BPD 3 dengan share kredit mencapai 52,9\%, BPD 5 26,5\% dan BPD lainnya dengan share kurang dari $20 \%$. 


\section{III.2. Analisis Default Risk Kredit Kecil untuk Plafon Hingga Rp 100 juta.}

\section{III.2.1. Analisis Default Risk Bank Umum Non BPD}

Default rate kredit kecil untuk plafon hingga Rp 100 juta bank umum non BPD mengalami peningkatan pada tahun 2003, yaitu dari rata-rata sebesar negatif $0,005 \%$ menjadi $0,675 \%$. Peningkatan deault risk tersebut terjadi akibat meningkatnya kecenderungan default risk masingmasing bank, sebagai akibat meningkatnya volatilitas dari aset. Sedangkan pada saat yang bersamaan dari data kredit macet bank, menunjukkan terjadi peningkatan kredit macet untuk kredit kecil dengan plafon hingga Rp 100 juta, yaitu dari rata-rata tingkat kemacetan sebesar

\begin{tabular}{|c|c|c|c|c|}
\hline & Default & $\begin{array}{l}\text { Tkt Macet } \\
\text { kriteria } \mathrm{BI}\end{array}$ & Agunan & $\begin{array}{l}\text { Share thd } \\
\text { total krd }\end{array}$ \\
\hline & \multicolumn{4}{|c|}{2002} \\
\hline BANK UMUM 1 & -0.91 & 0.15 & 775.20 & 1.67 \\
\hline BANK UMUM 2 & -0.01 & 0.31 & 24.20 & 2.18 \\
\hline BANK UMUM 3 & 0.44 & 2.05 & 4.35 & 2.51 \\
\hline BANK UMUM 4 & -0.16 & 2.33 & 121.8 & 1.67 \\
\hline BANK UMUM 5 & 0.34 & 1.43 & 4.488 & 2.85 \\
\hline BANK UMUM 6 & 0.27 & 1.0 & 7.50 & 1.12 \\
\hline \multirow[t]{2}{*}{ IHSG_STDEV } & 11.9 & & & \\
\hline & \multicolumn{4}{|c|}{2003} \\
\hline BANK UMUM 1 & -0.78 & 0.33 & 702.3 & 0.68 \\
\hline BANK UMUM 2 & 0.39 & 0.47 & 19.20 & 1.53 \\
\hline BANK UMUM 3 & 2.01 & 3.15 & 3.75 & 2.53 \\
\hline BANK UMUM 4 & -0.15 & 2.29 & 130.9 & 1.20 \\
\hline BANK UMUM 5 & 1.13 & 0.70 & 9.83 & 1.67 \\
\hline BANK UMUM 6 & 1.45 & 6.2 & 6.90 & 1.19 \\
\hline IHSG_STDEV & 14.6 & & & \\
\hline
\end{tabular}

1,21 \% pada tahun 2002 menjadi 2,56 \% pada tahun 2003. tingkat kemacetan tersebut berada diatas tingkat default risk dari hasil perhitungan.

Default risk yang rendah pada Bank Umum 1 dan Bank Umum 4 terjadi karena agunan yang ditetapkan oleh bank bagi kredit kecil tersebut jauh diatas nilai kreditnya yaitu pada tahun 2003 mencapai 702,3\% bagi agunan kredit Bank Umum 1 dan mencapai 130,9\% bagi 
kredit yang disalurkan oleh Bank Umum 4. Meskipun nilai agunan kredit Bank Umum lainnya berada jauh dibawah nilai kreditnya.

Share kredit kecil dengan plafon hingga Rp 100 juta pada bank umum non BPD rata-rata hanya sebesar 1,47 \% pada tahun 2003. Rendahnya share kredit ini menunjukkan bank umum tidak mengkonsentransikan kredit pada kelompok usaha ini.

\section{III.2.2. Analisis Default Risk Bank Pembangunan Daerah.}

Default risk kredit kecil BPD untuk plafon hingga Rp 100 juta menunjukkan peningkatan. Secara rata-rata meningkat dari $\quad$,34\% pada tahun 2002 menjadi $1,68 \%$ pada tahun 2003 . Peningkatan terbesar rata-rata terjadi pada akhir tahun 2003, kecuali default risk BPD 2 yang menunjukkan perkembangan default risk yang relatif stabil, dengan tingkat default risk 0,02 \% tahun 2002 dan 0,05\% pada tahun 2003. Posisi default risk terbesar pada tahun 2003 terjadi BPD 3 dan BPD 4 masing-masing mencapai 2,48\%, selanjutnya BPD 1 mencapai 2,19\%, BPD 6 mencapai 1,99\%, dan BPD 5 mencapai 0,90\% .

Tabel V.5 Rata-rata Default Risk, Kredit Macet Kriteria Bank Indonesia, Agunan Kredit dan Share Terhadap Total Kredit Kredit Kecil Bank Pembangunan Daerah Untuk Plafon Hingga Rp 100 juta Tahun $2002-2003$ (prosentase)

\begin{tabular}{|c|c|c|c|c|}
\hline & Default & $\begin{array}{l}\text { Krd Macet } \\
\text { kriteria BI }\end{array}$ & Agunan Krd & $\begin{array}{l}\text { Share thd } \\
\text { total krd }\end{array}$ \\
\hline & \multicolumn{4}{|c|}{2002} \\
\hline BPD 1 & 0.72 & 0.29 & 0.56 & 2.87 \\
\hline BPD 2 & 0.02 & 0.51 & 23.9 & 1.35 \\
\hline BPD 3 & 0.71 & 2.11 & - & 1.84 \\
\hline BPD 4 & 0.19 & 1.61 & 23.8 & 4.52 \\
\hline BPD 5 & 0.05 & 0.00 & 27.9 & 2.43 \\
\hline BPD 6 & 0.37 & 2.65 & 4.64 & 2.40 \\
\hline \multirow[t]{2}{*}{ IHSG_STDEV } & 11.9 & & & \\
\hline & \multicolumn{4}{|c|}{2003} \\
\hline BPD 1 & 2.19 & 0.38 & 0.25 & 3.19 \\
\hline BPD 2 & 0.05 & 0.74 & 33.2 & 0.94 \\
\hline BPD 3 & 2.48 & 1.11 & 0.13 & 1.50 \\
\hline BPD 4 & 2.48 & 1.61 & 1.9 & 3.17 \\
\hline BPD 5 & 0.90 & 1.01 & 9.0 & 6.55 \\
\hline BPD 6 & 1.99 & 2.32 & 4.42 & 3.56 \\
\hline IHSG_STDEV & 14.6 & & & \\
\hline
\end{tabular}


Rata-rata kredit macet pada tahun 2002 dan tahun 2003 tidak mengalami perubahan yaitu sebesar $1,20 \%$. Walaupun dalam perhitungan default risk menunjukkan peningkatan dari 0,34\% tahun 2002 menjadi 1,68\% pada tahun 2003. Posisi tingkat default risk lebih tinggi dibanding dengan tingkat kolektibilitas macet pada tahun 2002 terjadi pada BPD 1 dan BPD 5, sedangkan pada tahun 2003 terjadi pada BPD 1, BPD 3 dan BPD 4.

Dari data agunan kredit bank yang diperoleh dari laporan bulanan bank menunjukkan beberapa bank tidak memiliki agunan bagi kredit kecil untuk plafon hingga Rp 100 juta, sebagaimana terlihat pada BPD 3, dengan tingkat default risk mencapai 0,71\% tahun 2002 dan $2,48 \%$ pada tahun 2003. Sedang bank BPD yang memiliki agunan tertinggi, yaitu BPD 2 memiliki agunan kredit rata-rata 33,2\% pada tahun 2003.

Dari share kredit tampak bahwa untuk kredit kecil dengan plafon Rp 100 juta tidak banyak diberikan oleh BPD, dimana share kredit tersebut terhadap total kredit masing-masing bank tidak lebih dari 8\%, bahkan rata-rata share terhadap total kredit pada tahun 2002 mencapai 2,57\% dan pada tahun 2003 mencapai 3,15\%.

\section{III.3. Analisis Default Risk Kredit Kecil untuk Plafon Antara Rp 100 jt - Rp 500 jt. \\ III.3.1. Analisis Default Risk Bank Umum Non BPD}

Hasil perhitungan default risk untuk kredit kecil dengan plafon antara Rp 100 juta hingga Rp 500 juta yang disalurkan oleh bank umum non BPD menunjukkan rata-rata default risk tahun 2002 sebesar 0,05\% dan tahun 2003 sebesar 0,60\%. Beberapa bank bahkan mengalami tingkat default risk negatif dari waktu ke waktu, seperti Bank Umum 1, Bank Umum 4 dan Bank Umum 2. Sedang bank lainnya mengalami peningkatan default risk yang tajam pada akhir tahun 2003. Peningkatan volatilitas IHSG menyebabkan peningkatan default risk pada kredit bank umum. Bank-bank yang mengalami peningkat default risk adalah Bank Umum 3, Bank Umum 6 dan Bank Umum 5.

Jika dibandingkan antara default risk dengan data kredit macet bank maka rata-rata tingkat kredit macet bank lebih tinggi dibanding dengan rata-rata default risk bank, kecuali default risk Bank Umum 5 pada tahun 2003 yang tercatat sebesar 1,31\% dan kolektibilitas macet sebesar 0,38\%. Tingkat default risk lebih tinggi dibandingkan dengan kolektibilitas macet terjadi pada Bank Umum 5 pada tahun 2003, yaitu kolektibiltas macet sebesar 0,38 \% dengaan default risk sebesar $1,31 \%$.

Bank Umum 1 dan Bank Umum 4 memiliki tingkat default yang rendah bahkan selalu negatif memiliki agunan yang sangat memadai yaitu diatas $100 \%$ untuk Bank Umum 1 dan 
agunan 94,6\% untuk Bank Umum 4 pada tahun 2003. Meskipun demikian pada Bank Umum 2 dengan tingkat default risk tahun 2002 sebesar - 0,07\% memiliki agunan rata-rata 44,3\% dan untuk tahun 2003 dengan default risk sebesar 0,04\%, didukung dengan agunan rata-rata sebesar 37,1\%. Untuk Bank Umum 3, Bank Umum 5 dan Bank Umum 6 dengan agunan dibawah 10\% menujukkan default tahun 2002 kurang dari $1 \%$, yang selanjutnya pada tahun 2003 mengalami peningkatan default masing-masing menjadi 1,52\% untuk Bank Umum 3, 1,31\% untuk Bank Umum 5 dan 1,03\% untuk Bank Umum 6.

\begin{tabular}{|c|c|c|c|c|}
\hline & Default & $\begin{array}{l}\text { Krd Macet } \\
\text { kriteria BI }\end{array}$ & Agunan Krd & $\begin{array}{l}\text { Share thd } \\
\text { total krd }\end{array}$ \\
\hline & \multicolumn{4}{|c|}{2002} \\
\hline BANK UMUM 1 & -0.43 & 0.25 & 358.2 & 3.15 \\
\hline BANK UMUM 2 & -0.07 & 1.04 & 44.3 & 3.69 \\
\hline BANK UMUM 3 & 0.30 & 2.00 & 5.17 & 5.65 \\
\hline BANK UMUM 4 & -0.15 & 3.03 & 114.9 & 6.39 \\
\hline BANK UMUM 5 & 0.69 & 0.99 & 7.6 & 5.94 \\
\hline \multirow{3}{*}{$\begin{array}{c}\text { BANK UMUM } 6 \\
\text { IHSG_STDEV }\end{array}$} & -0.02 & 3.91 & 6.5 & 1.37 \\
\hline & 11.9 & & & \\
\hline & \multicolumn{4}{|c|}{2003} \\
\hline BANK UMUM 1 & -0.22 & 0.31 & 189.4 & 2.48 \\
\hline BANK UMUM 2 & 0.04 & 0.78 & 37.1 & 3.74 \\
\hline BANK UMUM 3 & 1.52 & 2.26 & 4.60 & 7.26 \\
\hline BANK UMUM 4 & -0.11 & 2.48 & 94.6 & 4.75 \\
\hline BANK UMUM 5 & 1.31 & 0.38 & 5.7 & 4.69 \\
\hline BANK UMUM 6 & 1.03 & 7.24 & 8.1 & 1.55 \\
\hline IHSG_STDEV & 14.6 & & & \\
\hline
\end{tabular}

Dari data laporan bulanan bank, share kredit dengan plafon antara Rp 100 juta hingga Rp 500 juta di bank umum non BPD rata - rata mencapai 4,37\% pada tahun 2002 dan 4,08\% pada tahun 2003.

\section{III.3.2. Analisis Default Risk Bank Pembangunan Daerah}

Default risk kredit kecil untuk plafon antara Rp 100 juta hingga Rp 500 juta Bank Pembangunan Daerah menunjukkan tren meningkat seiring dengan perkembangan resiko 
volatilitas harga aset. Default risk BPD rata-rata pada tahun 2002 mecapai 0,43\%, dan pada tahun 2003 meningkat menjadi 1,54\%. Posisi default pada tahun 2003 tertinggi adalah Bpd 3 yang mencapai 2,48\%, selanjutnya BPD 4 2,07\%, BPD 5 1,75\% dan BPD 1 1,53\%. Sedang BPD lainnya berada dibawah $1 \%$.

Perkembangan default risk yang cenderung meningkat tersebut berbeda dengan perkembangan kredit macet kriteria Bank Indonesia yang menunjukkan kecenderungan menurun, yang ditandai dengan penurunan kolektibilitas macet rata-rata BPD dari 1,88\% pada tahun 2002 menjadi 1,59\% pada tahun 2003.

\section{Tabel V.7 Rata-rata Default Risk, Kredit Macet Kriteria Bank Indonesia, Agunan Kredit dan Share Terhadap Total Kredit Kredit Kecil Bank Pembangunan Daerah Untuk Plafon Antara Rp 100 juta Hingga Rp 500 juta Tahun $2002-2003$ (prosentase)}

\begin{tabular}{|c|c|c|c|c|}
\hline & Default & $\begin{array}{l}\text { Krd Macet } \\
\text { kriteria BI }\end{array}$ & Agunan Krd & $\begin{array}{l}\text { Share thd } \\
\text { total krd }\end{array}$ \\
\hline & \multicolumn{4}{|c|}{2002} \\
\hline BPD 1 & 0.69 & 0.25 & 0.22 & 3.74 \\
\hline BPD 2 & 0.40 & 0.22 & 13.6 & 2.02 \\
\hline BPD 3 & 0.87 & 1.52 & 0.17 & 1.62 \\
\hline BPD 4 & 0.00 & 0.68 & 22.3 & 13.5 \\
\hline BPD 5 & 0.52 & 0.00 & 4.9 & 0.67 \\
\hline BPD 6 & 0.11 & 8.6 & 14.8 & 3.88 \\
\hline \multirow[t]{2}{*}{ IHSG_STDEV } & 11.9 & & & \\
\hline & \multicolumn{4}{|c|}{2003} \\
\hline BPD 1 & 1.53 & 0.77 & 0.50 & 4.15 \\
\hline BPD 2 & 0.47 & 1.42 & 15.1 & 1.73 \\
\hline BPD 3 & 2.48 & 0.66 & 0.07 & 1.46 \\
\hline BPD 4 & 2.07 & 1.88 & 1.4 & 7.7 \\
\hline BPD 5 & 1.75 & 1.02 & 6.8 & 0.70 \\
\hline BPD 6 & 0.93 & 3.8 & 11.1 & 3.63 \\
\hline IHSG_STDEV & 14.6 & & & \\
\hline
\end{tabular}

Agunan kredit BPD untuk plafon kredit ini pada tahun 2002 mencapai rata-rata 10,16\% dan pada tahun 2003 mencapai 9,27\% . Penurunan agunan yang terjadi pada saat yang bersamaan volatilitas harga aset mengalami peningkatan telah menyebabkan terjadi peningkatan default risk dari 0,43\% pada tahun 2002 menjadi 1,54\% pada tahun 2003. Posisi default pada tahun 2003 tertinggi pada BPD 3 yang mencapai 2,48\%, BPD 4 mencapai 2,07\%, dan BPD 5 mencapai 1,75\% terjadi sebagai akibat rendahnya agunan kredit yaitu masing masing sebesar 0,07\% untuk BPD 3, 1,4\% untuk BPD 4 dan 6,8\% untuk BPD 5. 
Share kredit bank BPD untuk kredit kecil dengan plafon antara Rp 100 juta hingga Rp 500 juta menunjukkan posisi yang relatif stabil kecuali share kredit yang di salurkan oleh BPD 4. Share kredit tersebut dari BPD 4 mengalami penurunan dari share rata-rata 13,5\% pada tahun 2002 menjadi 7,7\% pada tahun 2003. Adapun share untuk BPD lainnya untuk rata-rata tahun 2003 adalah berada dibawah 5\%.

\section{ANALISIS KAPASITAS PENJAMINAN KREDIT LEMBAGA PENJAMINAN KREDIT DAN SKEMA PENJAMINAN KREDIT}

\section{IV.1. Kapasitas Penjaminan Kredit Lembaga Penjaminan Kredit}

Dari perhitungan default risk, maka diperoleh rata-rata deafult risk tahun 2002 hingga tahun 2003 bagi seluruh bank umum untuk kredit mikro sebesar 0,77\%, kredit kecil dengan plafon s.d. Rp 100 juta sebesar 0,67\% dan kredit kecil dengan palfon antara Rp 100 juta hingga Rp 500 juta sebesar 0,65\%. Dengan rata-rata default risk untuk kredit UKM sebesar $0,70 \%$. Sehingga gearing ratio LPK untuk penjaminan kredit UKM adalah sebesar 142,72, yang berarti kapasitas penjaminan bagi LPK adalah sebesar 142,72 kali equity yang dimiliki. Dengan total equity yang sama, apabila sebuah LPK melakukan spesialisasi penjaminan pada jenis plafon kredit tertentu maka untuk masing-masing jenis kredit memberikan dampak kepada kapasitas penjaminan yang berbeda akibat dari perbedaan tingkat default risk .

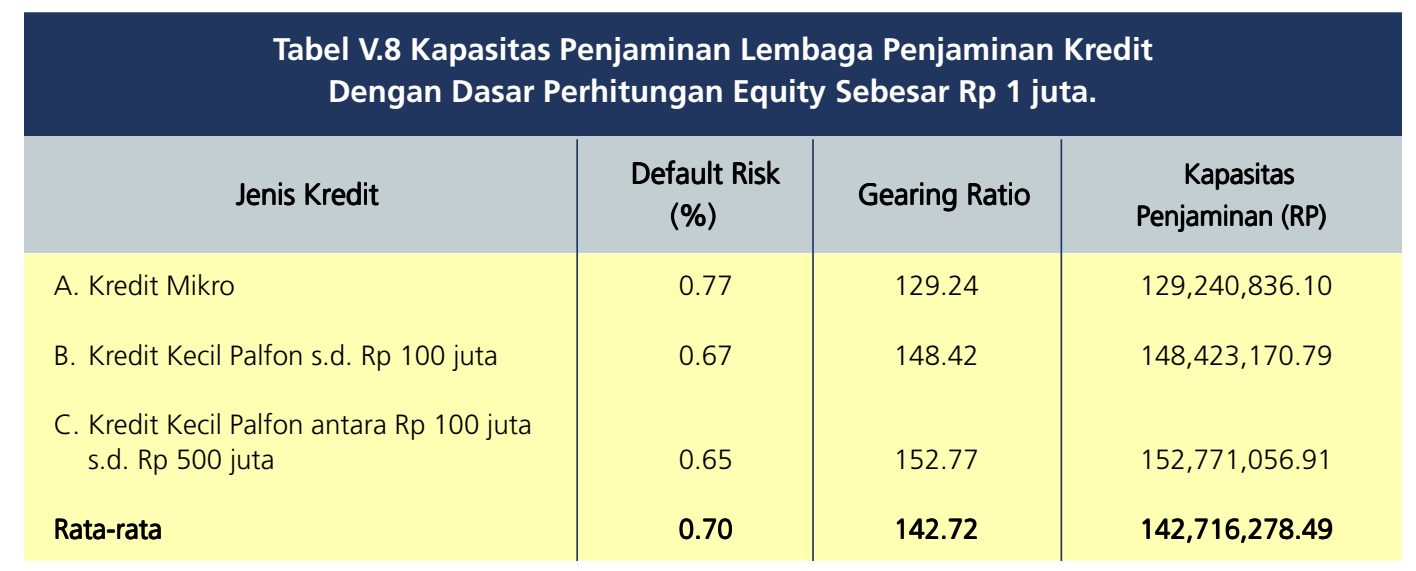

\section{IV.2. Skema Penjaminan Kredit}

Selain mempertimbangkan potensi pendanaan bantuan pengembangan UKM di masyarakat dan default risk kredit UKM, dalam menentukan pembagian resiko kredit perlu mempertimbangkan agunan kredit dan volatilitas harga aset. Makin tinggi agunan kredit maka 
tingkat default risk makin rendah karena nilai aset debitur menjadi semakin besar guna menutup kerugian karena fluktuasi harga aset. Sedangkan perhatian terhadap volatilitas harga aset dilakukan guna menentukan besar resiko yang harus ditanggung oleh pemerintah. Volatilitas harga aset dipengaruhi diantaranya oleh stabilitas perekonomian. Stabilitas perekonomian merupakan tanggung jawab pemerintah. Oleh karena itu resiko kredit macet yang dapat dibebankan kepada LPK dengan memperhatikan kelanggengan usaha LPK yaitu maksimum sebesar $70 \%$ dari sisa kewajiban debitur.

Dengan mengacu pada hasil perhitungan default risk kredit UKM dan dengan memperhatikan ketersediaan dana yang bersumber dari dana bergulir PEMDA, dan penyisihan keuntungan laba BUMN untuk pengembangan usaha mikro kecil serta program pengembangan UKM dari dinas terkait, maka dapat disusun beberapa alternatif skema penjaminan dan skema risk sharing bagi peningkatan penyaluran kredit UKM oleh perbankan.

\section{A. Model Kerjasama Antara Lembaga Penjamin Kredit Dengan Bank (Model Konvensional)}

Model kerja sama antara LPK dan Bank pada dasarnya telah umum dilakukan baik oleh PT ASKRINDO, Perum Sarana maupun PT PKPI, dengan pola penjaminan secara individual maupun secara portofolio. Dalam pelaksanaan di lapangan, model kerjasama ini perlu mendapat perhatian khususnya pada besarnya fee penjaminan, premium risk yang ditetapkan bank yang dimasukkan dalam variable penghitung bunga kredit dan besarnya risk sharing.

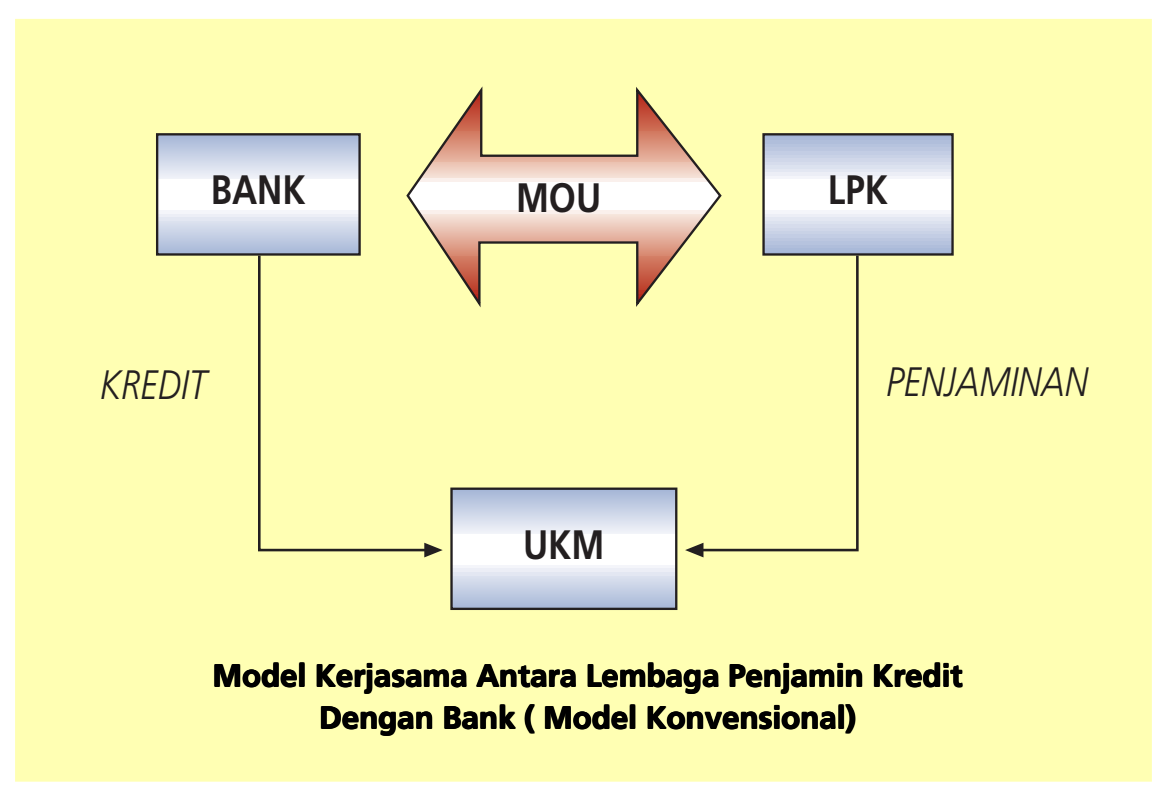


Setelah dilakukan penghitungan dengan pendekatan Merton, maka fee penjaminan dapat ditetapkan sebesar maksimum 0,70\% dari kredit UKM ditambah overhead cost dari LPK. Resiko yang ditanggung oleh LPK sebesar maksimum 70\% dari sisa kewajiban debitur. Bank menanggung resiko sebesar selisih realisasi default dengan kewajiban LPK. Oleh karena dalam pencairan kredit tersebut resiko sudah dialihkan ke LPK, maka bank tidak menambahkan faktor premium risk pada penghitungan suku bunga.

Risk Sharing :

\begin{tabular}{|l|l|l|}
\hline \multicolumn{2}{|c|}{ Tabel V.9 Karakteristik Risk Sharing, Bank vs. LPK } \\
\begin{tabular}{|l|l|}
\hline \multicolumn{1}{|c|}{ Bank } \\
b. Service charge/fee penjaminan
\end{tabular} & $\begin{array}{l}|c| \\
\text { Tidak ada } \\
\text { Tidak ada }\end{array}$ & $\begin{array}{l}\text { Tidak ada } \\
\text { Maksimum 0,70\% dari plafon } \\
\text { kredit + overhead cost } \\
\text { c. Maksimum resiko yg ditanggung } \\
\text { Secara komulatif maksimum 70\% } \\
\text { dari keajiban kredit UKM yang } \\
\text { dijaminkan }\end{array}$ \\
\hline
\end{tabular}

\section{B. Model Kerjasama PEMDA Dengan Lembaga Penjamin Kredit}

Model kerjasama antara LPK dengan PEMDA merupakan upaya mendorong pertumbuhan kredit perbankan dengan melibatkan PEMDA dalam penyediaan dana penjaminan yang merupakan dana APBD yang disisihkan guna pembinaan dan pengembangan UKM. Dalam

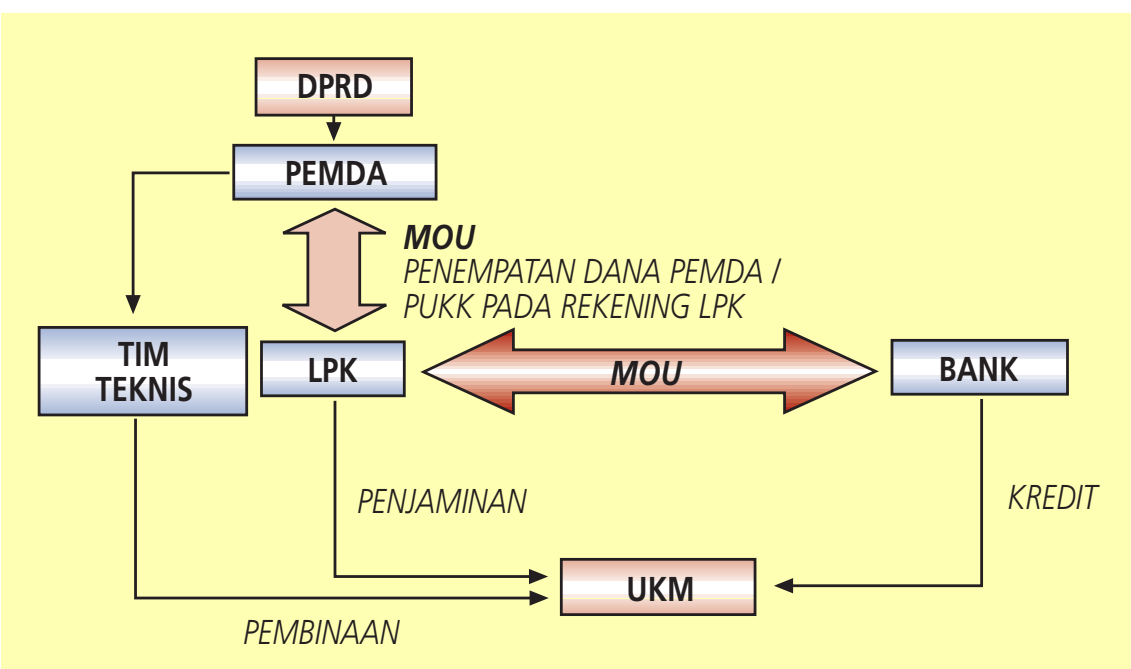

Model Kerjasama PEMDA Dengan Lembaga Penjamin Kredit 
pola ini PEMDA menjamin atas kredit UKM yang disalurkan oleh bank melalui kontrak kerjasama antara LPK dengan Bank. Pengusaha yang mengikuti pola ini adalah pengusaha binaan dari dinas terkait melalui Tim Teknis. Pemerintah daerah akan menempatkan sejumlah dana tertentu pada rekening LPK yang ada di bank sebagai sumber penjaminan.

Apabila terjadi default maka resiko akan ditanggung bersama antara LPK, bank dan PEMDA. Masimum resiko yang ditanggung LPK adalah sebesar $70 \%$ dari seluruh sisa kewajiban total kredit UKM atau sesuai denga perjanjian, sedangkan resiko yang ditanggung PEMDA dan Bank adalah masing-masing 50\% dari sisa resiko yang terjadi setelah dikurangi tanggung jawab LPK. Fee penjaminan yang dibebankan oleh LPK kepada debitur bank adalah sebesar 0,70\% sedangkan overhead cost dari LPK adalah berasal dari bunga simpanan dana PEMDA. Dengan demikian beban biaya program penjaminan kepada debitur UKM dapat ditekan. Alternatif lain dalam pola kerja sama ini adalah bahwa PEMDA mendukung permodalan dari LPK, dengan kata lain untuk mendukung kapasitas penjaminan dari LPK maka PEMDA akan menyuntikkan dananya.

Bank diharapkan tidak menambah premium risk dalam variabel penghitung suku bunga kredit, sedang selain fee penjaminan, dalam menutup operasional cost, maka LPK akan memanfaatkan hasil bunga penempatan dana PEMDA pada rekening LPK di Bank.

Risk Sharing :

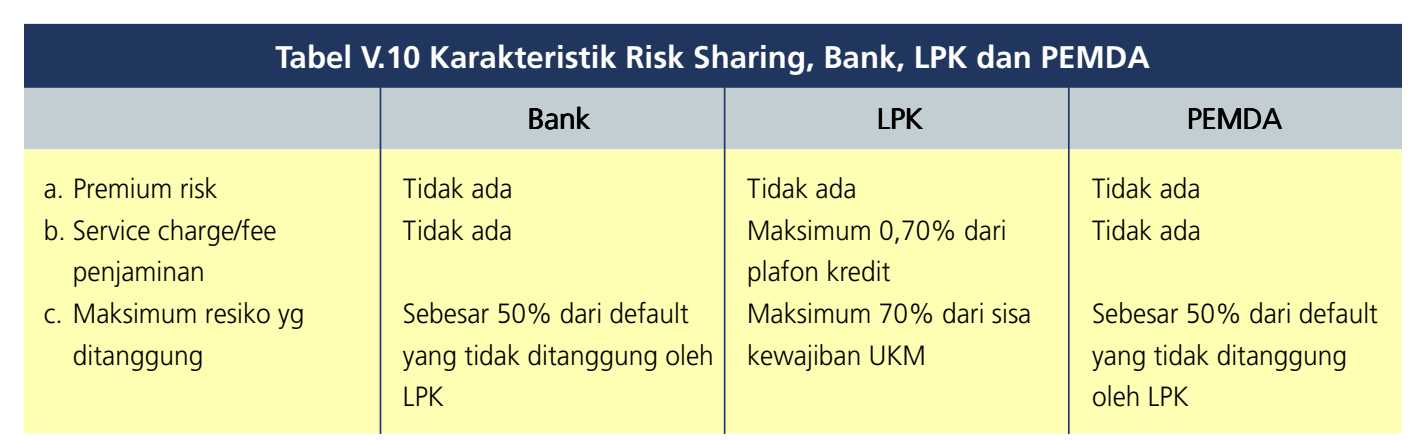

\section{Model Kerjasama Lembaga Penjamin Kredit Daerah Bentukan PEMDA Dengan Lembaga Penjamin Kredit}

Dalam upaya mengembangkan UKM dan koperasi, beberapa PEMDA, seperti PEMDA Riau, PEMDA Jawa Timur, PEMDA Sulawesi Selatan dan beberapa PEMDA lainnya telah merintis pendirian LPKD, yang hingga saat ini belum memperoleh ijin operasional dari Departemen Keuangan. Dengan bekerjasama dengan LPK yang telah beroperasi, maka LPKD tersebut dapat melakukan kegiatannya. Dalam hal ini dalam rangka penjaminan kredit UKM, maka LPKD akan melakukan MOU dengan LPK yang ada dan selanjutnya LPK melakukan MOU dengan bank 
dalam rangka penjaminan penyaluran kredit UKM. Dengan bentuk kerjasama ini diharapkan terjadi transfer pengetahuan dimana pada saat LPKD telah memperoleh ijin operasional maka dapat dengan segera melakukan kegiatannya. Sumber dana operasional dari LPKD adalah dari penyisihan dana PEMDA dengan persetujuan dari DPRD. Karena yang memiliki ijin operasional adalah LPK maka kontrak penjaminan akan dilakukan dengan menggunakan lembaga LPK meskipun dalam kegiatan operasionalnya dilakukan oleh LPKD.

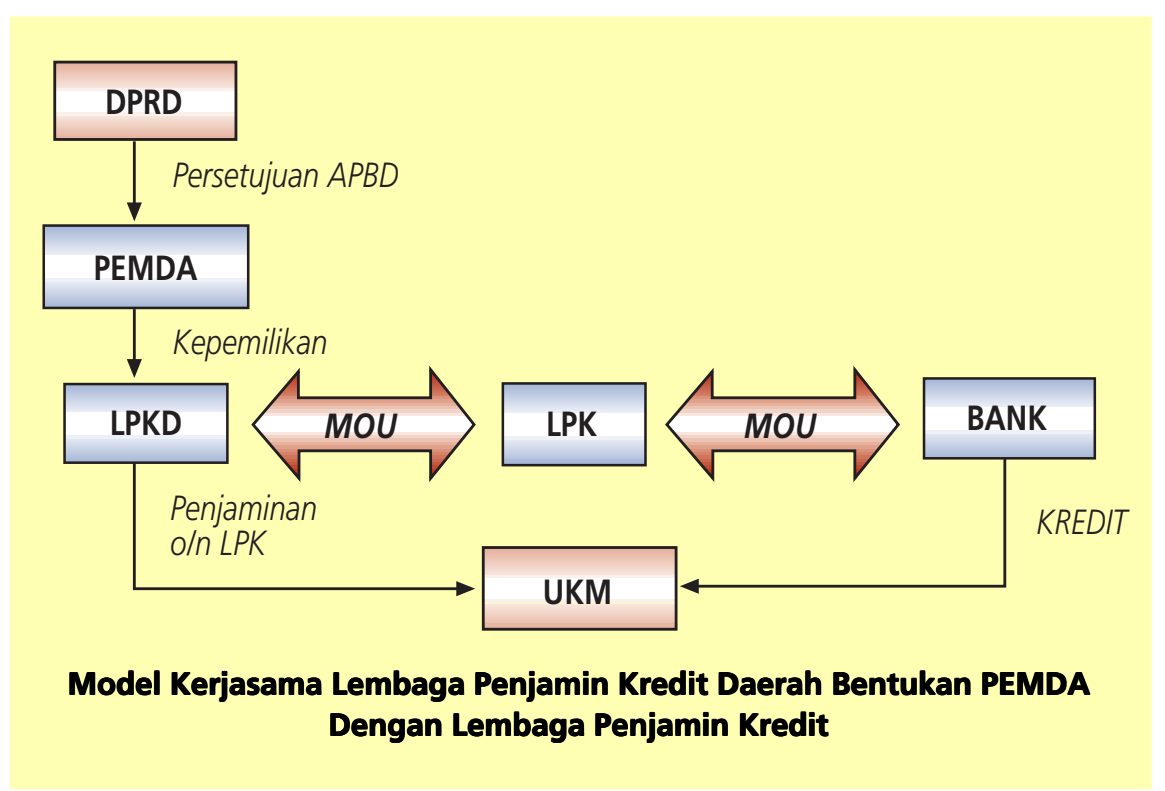

Dalam model ini, fee penjaminan diperuntukkan bagi kegiatan operasional LPK dan LPKD, dengan demikian selain tingkat default risk maka overhead cost bagi LPK dan LPKD dibebankan kepada debitur. Resiko yang ditanggung oleh LPK secara maksimum sebesar $70 \%$ dari total sisa kredit UKM. Kelebihan tersebut akan ditanggung oleh bank dan PEMDA.

Risk sharing :

Tabel V.11 Karakteristik Risk Sharing, Bank, LPK, LPKD/PEMDA

\begin{tabular}{l|l|l|l}
\hline \multicolumn{1}{|c|}{ Bank } & \multicolumn{1}{|c|}{ LPK } & \multicolumn{1}{|c}{ LPKD/PEMDA } \\
$\begin{array}{l}\text { a. Premium risk } \\
\text { b. Service charge/fee } \\
\text { penjaminan }\end{array}$ & Tidak ada & Tidak ada \\
Tidak ada & $\begin{array}{l}\text { Maksimum 0,70\% dari } \\
\text { plafon kredit + overhead cost }\end{array}$ & $\begin{array}{l}\text { Tidak ada } \\
\text { Overhead cost dengan } \\
\text { memperhitungkan bagian } \\
\text { dari LPK }\end{array}$ \\
$\begin{array}{l}\text { c. Maksimum resiko yg } \\
\text { ditanggung }\end{array}$ & $\begin{array}{l}\text { Sebesar 50\% dari default } \\
\text { yang tidak ditanggung oleh } \\
\text { LPK }\end{array}$ & $\begin{array}{l}\text { Secara komulatif maksimum } \\
70 \% \text { dari sisa kredit UKM } \\
\text { yang dijaminkan }\end{array}$ & $\begin{array}{l}\text { menanggung sebesar 50\% } \\
\text { dari default yang tidak } \\
\text { ditanggung oleh LPK }\end{array}$ \\
\hline
\end{tabular}




\section{Model Pengalihan Kredit Non Bank untuk UMKM Binaan PEMDA / BUMN Kepada Bank Dengan Penjaminan Dari Lembaga Penjamin Kredit}

Model ini dimaksudkan untuk meningkatkan perputaran dana bergulir PEMDA maupun laba BUMN/D yang disisihkan untuk pembinaan UKM. Usaha mikro kecil hasil binaan PEMDA atau BUMN yang sebelumnya belum bankable setelah memperoleh kredit langsung dari kedua institusi tersebut, apabila secara lancar dapat mengembalikan pinjamannya hingga $50 \%$, dalam kerangka pembinaan UKM dapat dialihkan ke kredit bank yang sekaligus dijamin oleh LPK. Kelancaran pengembalian kredit oleh UKM kepada PEMDA atau BUMN/D diperlukan untuk menguji karakter dari debitur dimaksud.

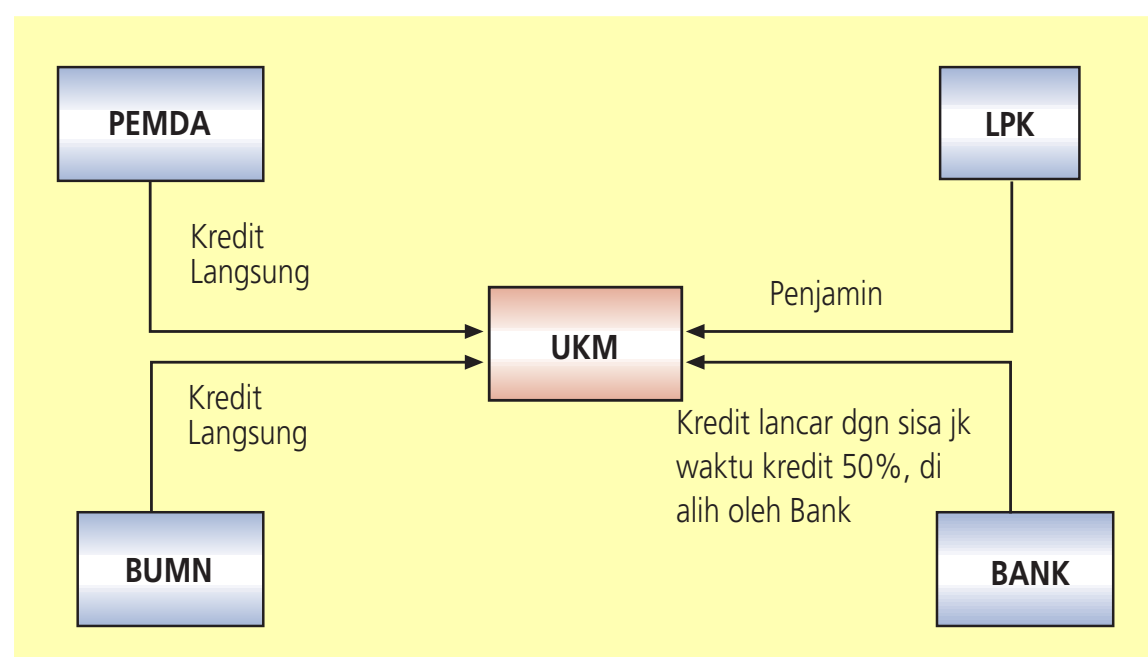

\section{Model Pengalihan Kredit Non Bank untuk UMKM Binaan PEMDA / BUMN Kepada Bank Dengan Penjaminan Dari Lembaga Penjamin Kredit}

Dalam model ini resiko yang ditanggung oleh bank dan LPK sebatas pada resiko pemberian kredit bank yang merupakan pelimpahan kredit dari PEMDA atau BUMN/D, dengan maksimum resiko adalah sebesar 70\% dari sisa kredit debitur UKM tersebut. Sedang resiko yang ditanggung oleh PEMDA dan BUMD adalah resiko kemacetan kredit yang tidak dapat dilimpahkan ke bank.

Risk sharing : 


\begin{tabular}{|c|c|c|c|c|}
\hline & Bank & LPK & PEMDA & BUMN \\
\hline a. Premium risk & Tidak ada & Tidak ada & Tidak ada & Tidak ada \\
\hline $\begin{array}{l}\text { b. Service charge/fee } \\
\text { penjaminan }\end{array}$ & Tidak ada & $\begin{array}{l}\text { Maksimum } 0,70 \% \text { dari } \\
\text { plafon kredit + overhead } \\
\text { cost }\end{array}$ & Tidak ada & Tidak ada \\
\hline $\begin{array}{l}\text { c. Maksimum resiko yg } \\
\text { ditanggung }\end{array}$ & $\begin{array}{l}\text { Sebesar default kredit } \\
\text { bank yang tidak } \\
\text { ditanggung oleh LPK }\end{array}$ & $\begin{array}{l}\text { Secara komulatif } \\
\text { maksimum } 70 \% \text { dari } \\
\text { sisa kredit UKM yang } \\
\text { dijaminkan }\end{array}$ & $\begin{array}{l}\text { Sebesar default kredit } \\
\text { yang tidak dialihkan } \\
\text { ke bank }\end{array}$ & $\begin{array}{l}\text { Sebesar default kredit } \\
\text { yang tidak dialihkan } \\
\text { ke bank }\end{array}$ \\
\hline
\end{tabular}

\section{E. Model Kerjasama Dengan Memanfaatan Konsultan Keuangan Mitra Bank (KKMB) Oleh} Lembaga Penjamin Kredit dan Bank

Konsultan Keuangan Mitra Bank (KKMB) menjembatani gap antara UKM dengan bank. KKMB berperan sebagai pembimbing UKM dalam penyusunan proposal kredit yang sesuai dengan standar bank, sehingga secara tidak langsung membantu bank dalam memudahkan penilaian kelayakan kredit UKM. Fungsi ini dapat pula dimanfaatkan oleh LPK yang akan menjamin kredit UKM. Oleh karena itu bank secara bersama-sama dengan LPK dapat memanfaatkan KKMB dalam menilai kelayakan usaha UKM. Pembentukan dan biaya operasional dari KKMB dilakukan oleh PEMDA dalam rangka pembinaan UKM dan Koperasi.

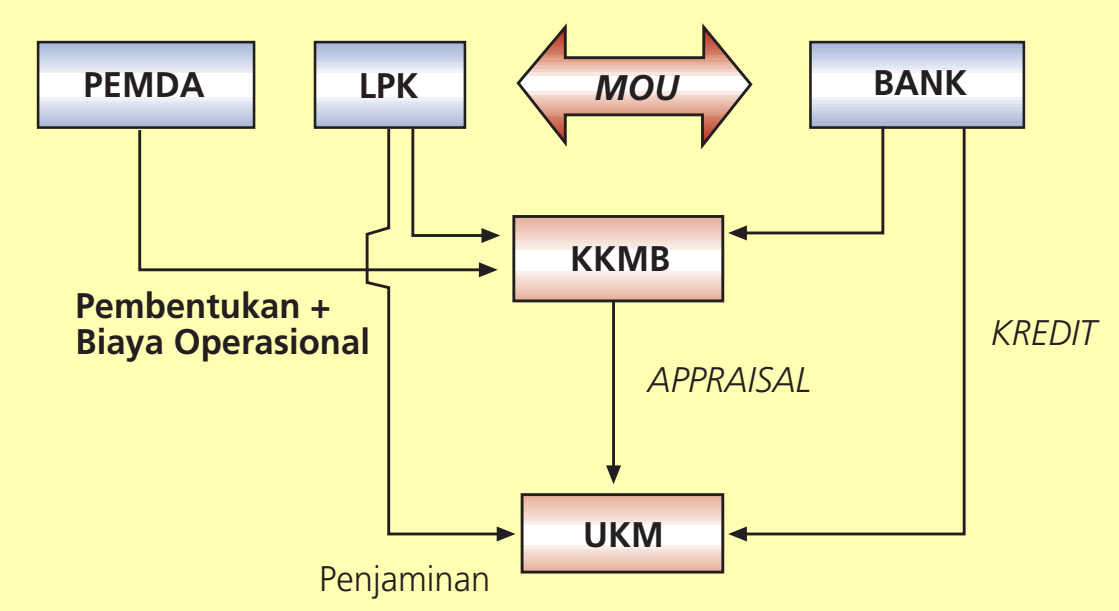

Model Kerjasama Dengan Memanfaatan Konsultan Keuangan Mitra Bank (KKMB) Oleh Lembaga Penjamin Kredit dan Bank 
Dalam model ini, resiko default akan ditanggung bersama antara LPK dengan bank dengan porsi yang menjadi tanggung jawab LPK adalah masimum sebesar $70 \%$ dari sisa kewajiban seluruh kredit UKM yang dijaminkan. Sedang sisanya ditanggung oleh bank. Dalam model ini pihak PEMDA dan KKMB tidak menanggung resiko default, karena keputusan kredit sepenuhnya dilakukan oleh Bank dengan penjaminan dari LPK.

Risk Sharing :

\begin{tabular}{|c|c|c|c|c|}
\hline & Bank & LPK & PEMDA & KKMB \\
\hline a. Premium risk & Tidak ada & Tidak ada & Tidak ada & Tidak ada \\
\hline $\begin{array}{l}\text { b. Service charge/fee } \\
\text { penjaminan }\end{array}$ & Tidak ada & $\begin{array}{l}\text { Maksimum 0,70\% dari } \\
\text { plafon kredit }\end{array}$ & Tidak ada & Tidak ada \\
\hline $\begin{array}{l}\text { c. Maksimum resiko yg } \\
\text { ditanggung }\end{array}$ & $\begin{array}{l}\text { Sebesar default kredit } \\
\text { bank yang tidak } \\
\text { ditanggung oleh LPK }\end{array}$ & $\begin{array}{l}\text { Maksimum } 70 \% \text { dari sisa } \\
\text { kewa-jiban kredit UKM } \\
\text { yang dijaminkan }\end{array}$ & Tidak ada & Tidak ada \\
\hline
\end{tabular}

\section{KESIMPULAN DAN SARAN}

\section{V.1. Kesimpulan}

Dengan pendekatan Merton didapat tingkat default risk kredit perbankan untuk kredit mikro sebesar 0,77\%, kredit kecil dengan plafon hingga Rp 100 juta sebesar 0,67\% dan kredit kecil dengan plafon antara Rp 100 juta hingga Rp 500 juta sebesar 0,65\%. Secara keseluruhan tingkat default risk untuk kredit UKM sebesar $0,70 \%$. Besarnya tingkat default risk yang rendah ini berbeda dengan tingkat kolektibilitas kategori macet kredit UKM kolektibilitas 5 sesuai ketentuan Bank Indonesia yang secara keseluruhan tercatat rata-rata sebesar 1,80\% dengan rincian untuk kredit mikro sebesar 1,81\%, kredit kecil dengan plafon hingga Rp 100 juta sebesar 1,69\% dan kredit dengan plafon anatar Rp 100 juta hingga Rp 500 juta sebesar 1,91\%. Hal ini terjadi karena adanya perbedaan pendekataan dari keduanya. Pendekatan metode Merton sepenuhnya mendasarkan pada pendekatan forward looking, sedang tingkat kolektibilitas kredit yang ditetapkan oleh Bank Indonesia lebih banyak mendasarkan pada pendekatan backward looking atas data yang digunakan.

Fluktuasi default risk terjadi lebih dikarenakan fluktuasi harga aset yang dicerminkan dari fluktuasi indeks harga saham. Sedangkan tren yang menurun dari suku bunga SBI 3 bulan sebagai variable free risk rate tidak memberikan dampak pada penekanan tingkat default risk.

Agunan yang rendah (sebagian besar antara 0\% hingga 37\%) pada kredit UKM dapat menghasilkan default risk rata-rata $0,70 \%$ sepanjang fluktuasi harga aset tidak melebihi 
$11 \%$. Makin tinggi agunan tambahan yang dipersyaratkan oleh bank kepada debitur akan menekan tingkat default risk. Namun dari kajian menunjukkan bahwa tingkat default risk pada dasarnya lebih banyak dipengaruhi oleh volatilitas harga aset.

Dengan menggunakan perhitungan gearing ratio dan dengan menggunakan hasil perhitungan default risk kredit UKM, maka diperoleh perhitungan kemampuan sebuah lembaga penjaminan kredit dalam menjamin kredit UKM sebesar 142,72 kali total equity LPK dimaksud. Makin tinggi tingkat default risk maka makin rendah kapasitas penjaminan dari LPK.

Terdapat beberapa alternatif skema penjaminan kredit mikro yang penerapannya disesuaikan dengan potensi sumber dana yang ada di masyarakat. Pemilihan skema penjaminan akan menentukan pula pada pembagian resiko pihak-pihak yang terlibat dalam pengembangan UKM. Resiko default tidak dapat sepenuhnya ditanggung oleh LPK mengingat dalam penilaian kelayakan kredit dilakukan oleh bank, sehingga agar ada kesungguhan dalam penilaian kredit, bank perlu menanggung resiko default kredit UKM. Adapun fee penjaminan dapat menggunakan hasil perhitungan default risk dengan pendekatan Merton.

\section{V.2. Saran}

a. Tingkat default risk dari hasil perhitungan Merton dapat dipergunakan sebagai acuan dalam penjaminan kredit oleh bank dan LPK, namun demikian tetap diperlukan unsur kehati-hatian dalam penilaian kredit khususnya terhadap karakter nasabah dan fisibilitas usaha debitur guna menekan default risk.

b. Karena volatilitas harga aset menunjukkan unsur dominan dalam menentukan default risk kredit UKM, maka pemerintah diharapkan dapat mengendalikan stabilitas harga aset, guna menekan tingkat default risk kredit UKM.

c. Pemerintah diharapkan segera mengeluarkan aturan mengenai kapasitas penjaminan suatu LPK, karena dari hasil perhitungan kapasitas penjaminan yang dihitung dari gearing rasio perusahaan menunjukkan kemampuan sebesar 142,72 kali total equity LPK. $\mathrm{Hal}$ ini sangat berbeda dari ketentuan kapasitas penjaminan suatu lembaga asuransi yang ditetapkan melalui kewajiban menjaga tingkat solvabilitas minimal sebesar 120\% dari resiko kerugian yang mungkin timbul sebagai akibat dari deviasi dalam pengelompokkan kekayaan dan kewajiban.

d. Skema penjaminan kredit UKM sebaiknya memanfaatkan potensi dana yang ada di masyarakat yaitu dana bergulir PEMDA dan dana penyisihan keuntungan BUMN/D. Hal 
ini akan memberikan manfaat ganda yaitu melatih UKM untuk tidak selalu memperoleh subsidi secara terus menerus dalam berusaha dan meningkatkan kemampuan UKM dalam berhubungan dengan bank. Subsidi dapat diberikan dalam bentuk penutupan fee penjaminan yang seharusnya dibebankan kepada debitur. 


\section{DAFTAR PUSTAKA}

Basle Committeee on Banking Supervision, April 1999, Credit Risk Modelling : current Practices and Aplications

Bernanke Ben, Gertler Mark, 2000, Monetary Policy and Asset Price Volatility, National Bureau Of Economic Research, Inc.

Biro Kredit - Bank Indonesia, 2003, Bahan Pelatihan : Pengembangan Hubungan Bank Dengan Kelompok Swadaya Masyarakat (PHBK), Bank Indonesia

Biro Kredit - Bank Indonesia, 2002, Penelitian Pola Pembiayaan Dalam Rangka Pengembangan Usaha Mikro dan Kecil Pasca UU BI No. 23/1999, Biro Kredit Bank Indonesia.

Coyle, Brian, 2000, Framework For Credit risk Management, CIB Publishing

Coyle, Brian, 2000, Measuring Credit Risk, CIB Publishing

Coleshaw John, 1989, Credit Analysis - How to Measure and Manage Credit Risk, Woodhead-Faulkner Limited, England.

Direktorat Riset Ekonomi dan Kebijakan Moneter Bank Indonesia, 2001, Credit Crunch di Indonesia Setelah Krisis, Bank Indonesia,

Eales Rob, 1997, Credit Risk Measurement in Corporate Banking - Theory and Practice, Reserve bank of Australia Bank Supervition Department

Gibson H. Charles, 1998, Financial Statement Analysis, South-Western College Publishing, Cincinnati - Ohio,

Kesepakatan bersama Pemerintah Kabupaten Malang dengan PT BPD Jawa Timur Cabang Malang No 040/278/KRD-PROGCML / 2002

Kesepakatan bersama antara Yayasan Damandiri, PT BPD Jawa Timur dan Universitas Muhammadiyah Malang No. 135/WAKA-I/YDSM/X/2002 tentang Pengembangan dan Pemberdayaan Ekonomi Masyarakat Sekitar Kampus

Keputusan Bupati Selayar No 244 tahun 2000 tentang Mekanisme Peminjaman Dana Pemberdayaan Masyarakat Tani/Nelayan/Industri Kecil Pada BPD Cabnag Selayar

Keputusan Bupati Takalar No. 182 tahun 2002 tgl 8 Agustus 2002 tetang Petujuk Teknis Penyaluran KUPERTA TA 2002 
Navajas Ruiz Alvaro, 2001, Credit Guarantee Schemes: Conceptual Frame, Financial System Development Project, GTZ/FONDESIF

Perjanjian kerjasama tentang Proyek Penyaluran Dana Penguatan / Pengembangan Modal Usaha TA 2002, nomer 180/111/435.110/2002

Perjanjian Kerjasama Antara Pemerintah Kabupaten Gowa dengan BPD Sul-sel Cabang Gowa, No 580/034/EKONOMI tentang Penyaluran Dana Avalis Pemerintah Kabupaten Gowa

Perjanjian Kerjasama antara PEMDA kota Parepare dengan BPD Sulsel Cab Parepare No. 7/KB/NIII/2003; No KK/01/PR/2003 tetang Penyempurnaan Penyaluran Dana Avalis Pola Eksekuting dan Chanelling PEMDA Kota Parepare

Perjanjian Kerjasama antara PEMDA kota Parepare dengan BPD Sulsel Cab Parepare No. 7/KB/NIII/2003 ; No KK/01/PR/2003 tetang Penyempurnaan Penyaluran Dana Avalis Pola Eksekuting dan Chanelling PEMDA Kota Parepare

Reserve Bank Of Australia, 1997, Credit Risk in Banking, Alken Press Pty.

Saunders Anthony, 1999, Credit Risk Measurement New Approaches to Value at Risak and Other Paradigms, John Wiley \& Sons Inc, Canada.

Teweles J. Richard, Bradley S. Edward, Teweles M. Ted, 1992, The Stock Market, John Wiley \& Sons, Inc, Canada, $6^{\text {th }}$ edition

Ullmer Michael, May 1997, Managing Credit Risk - An Overview, Credit Risk In Banking, Bank Supervision Department, Reserve Bank of Australia

www.perum-sarana.com 
halaman ini sengaja dikosongkan 